\title{
To Facilitate or Curb? The Role of Financial Development in China's Carbon Emissions Reduction Process: A Novel Approach
}

\author{
Tiancai Xing ${ }^{1}$, Qichuan Jiang ${ }^{1, *}$ and Xuejiao $\mathrm{Ma}^{2}$ \\ 1 School of Finance, Dongbei University of Finance and Economics, Dalian 116023, China; \\ xingtiancai@126.com \\ 2 School of Statistics, Dongbei University of Finance and Economics, Dalian 116023, China; \\ xuejiaomadufe@163.com \\ * Correspondence: jiangqichuan123@163.com; Tel.: +86-183-4222-0940
}

Received: 5 September 2017; Accepted: 10 October 2017; Published: 13 October 2017

\begin{abstract}
With the Paris Agreement coming into effect, $\mathrm{China}$, as the largest $\mathrm{CO}_{2}$ emitter in the world, will be facing greater pressure to reduce its carbon emissions. This paper discusses how to solve this issue from the perspective of financial development in China. Although many studies have analyzed its impact on carbon emissions, the conclusions are contradictory. A major criticism of the existing studies is the reasonability of the selection of appropriate indicators and panel estimation techniques. Almost all studies use only one or limited indicators to represent the financial development and ignore the cross-sectional dependence. To fulfil the gaps mentioned above, a financial development index system is built, and with the framework of the STIRPAT (Stochastic impacts by regression on population, affluence, and technology) model, this paper applies an ARDL approach to investigating the long-run relationship between financial development and carbon emissions and a dynamic panel error-corrected model to capture the short-run impact. The empirical results show that financial development can improve carbon emissions, and such impact not only shows a regional difference but also reflects the features of stage differences. Additionally, based on the discussion on seven specific aspects of financial development, our findings can be helpful for policy makers to enact corresponding policies to realize the goal of reducing carbon emissions in China.
\end{abstract}

Keywords: financial development; carbon emissions; financial development index system; STIRPAT model; dynamic panel data analysis; regional and stage analysis

\section{Introduction}

The notion that only developed countries face environmental degradation is invalid, at least in terms of consequences, because the greenhouse gases have an enormously negative impact on both developing and developed countries regardless of the source of the gases [1]. The burning of fossil fuels and human activities results in a large increase in the concentration of greenhouse gases, which causes the extreme climate events and seriously deteriorates living conditions for humans [2]. On the one hand, global warming will aggravate destruction of the environment, which will result in a more frequent and lasting extreme climate, such as tornadoes and droughts. From 1900 to 2015, the global average temperature rose by $1.02{ }^{\circ} \mathrm{C}$ [3]. On the other hand, climate change is greatly challenging the sustainability of human society and threatening human health, causing respiratory disease and malnutrition [4].

According to Global Carbon Projects [5], the total amount of carbon emissions and carbon emissions per capita is 36 billion tons and 5 tons, respectively, which set a new historical record. The concentration of all greenhouse gases continues to increase, and the greenhouse gas index in 
2015 is $37 \%$ higher than that in 1990 , among which the contribution of $\mathrm{CO}_{2}$ is approximately $80 \%$. Figure 1 demonstrates the distribution of carbon emissions in the world, which also verifies that China has surpassed the European Union and the U.S. and has become the largest carbon emitter in the world [6]. In Figure 2, the energy structure of China, the U.S., the European Union, India, Russia, Indonesia, Brazil and Japan can be seen clearly. Coal, oil and natural gas are three main sources for carbon emissions.

\section{Carbon emissions of the main world economies in 2015 \\ China has become the largest carbon emitter in the world, which should be valued greatly. The carbon emissions of China have exceeded the sum of the US and European Union.}

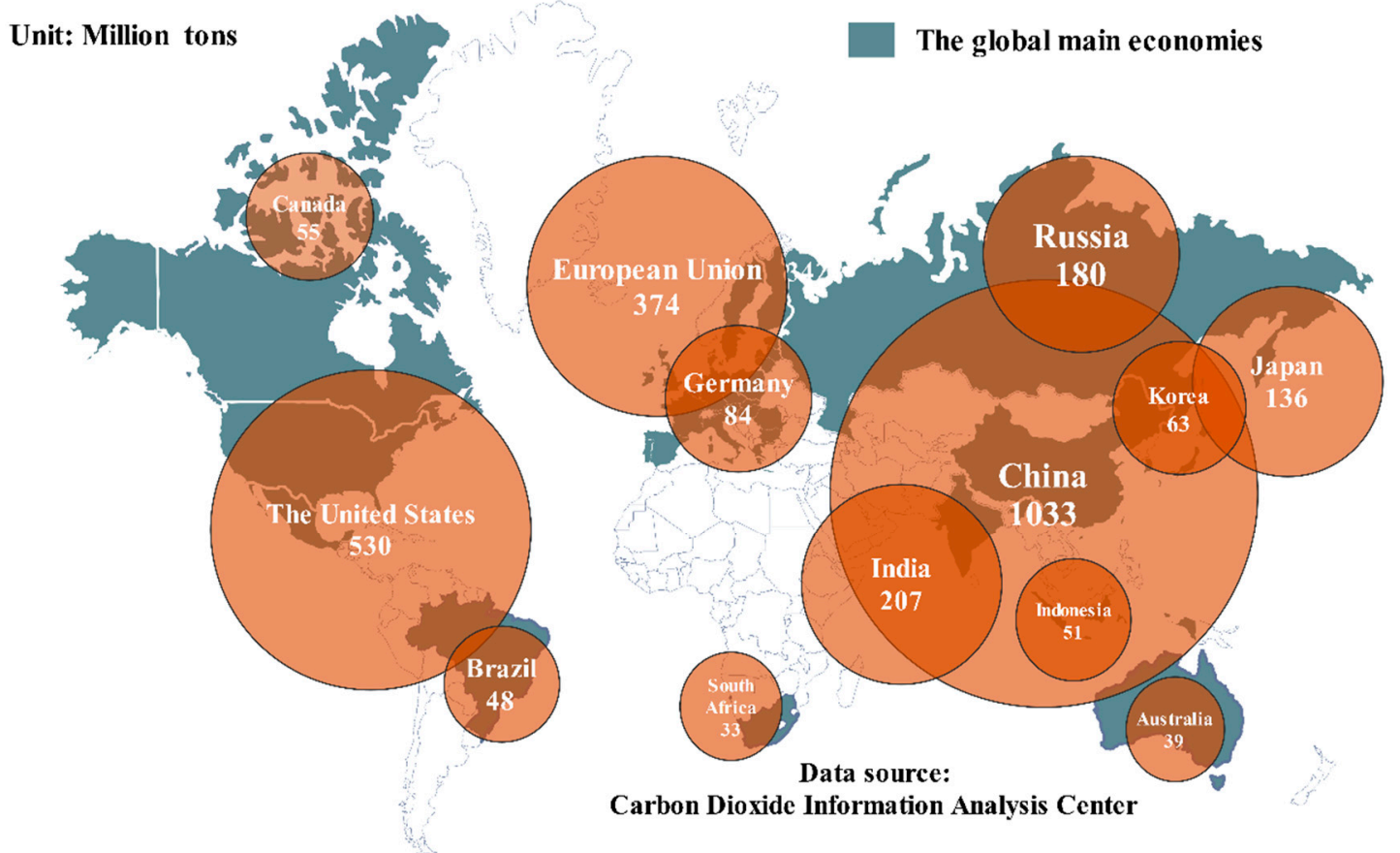

Figure 1. Carbon emissions of the main world economies in 2015.

To address the issue of climate change, the global community has agreed that each country is to adopt measures to alleviate global warming, such as improving energy use efficiency [7]. The European Union has implemented an Emission Trading Scheme and proposed to reduce carbon emissions by approximately $20-30 \%$ by 2020 . The UK was the first county to include emission reduction into a legal framework. China began to focus on energy and environmental problems in the 21st century, and a series of effective measures have been taken. In 2009, China promised that carbon emissions reduction would be included in the middle- and long-term development plan for the national economy and social development as an obligatory target, and the carbon emission intensity (CEI) in 2030 would decrease by $60-65 \%$ compared to that in 2005 [8], which shows a great determination on China's part to reduce carbon emissions. Since 2000, China has made large contributions to reducing carbon emissions, and its detailed policies are listed in Appendix A, Table A1.

According to CDIAC [9], the Chinese carbon emissions levels have staged characteristics, which can be divided into the following four phases: (1) 1978-1995. The emission of carbon dioxide increased year by year with a relatively slow growth rate of approximately $5.3 \%$; (2) 1996-2001. Carbon emissions nearly stopped and decreased; (3) 2002-2009. China's carbon emissions increased rapidly, and in 2006, China surpassed the U.S., becoming the largest carbon emitter in the world; (4) 2003-2015. Growth again slowed. 


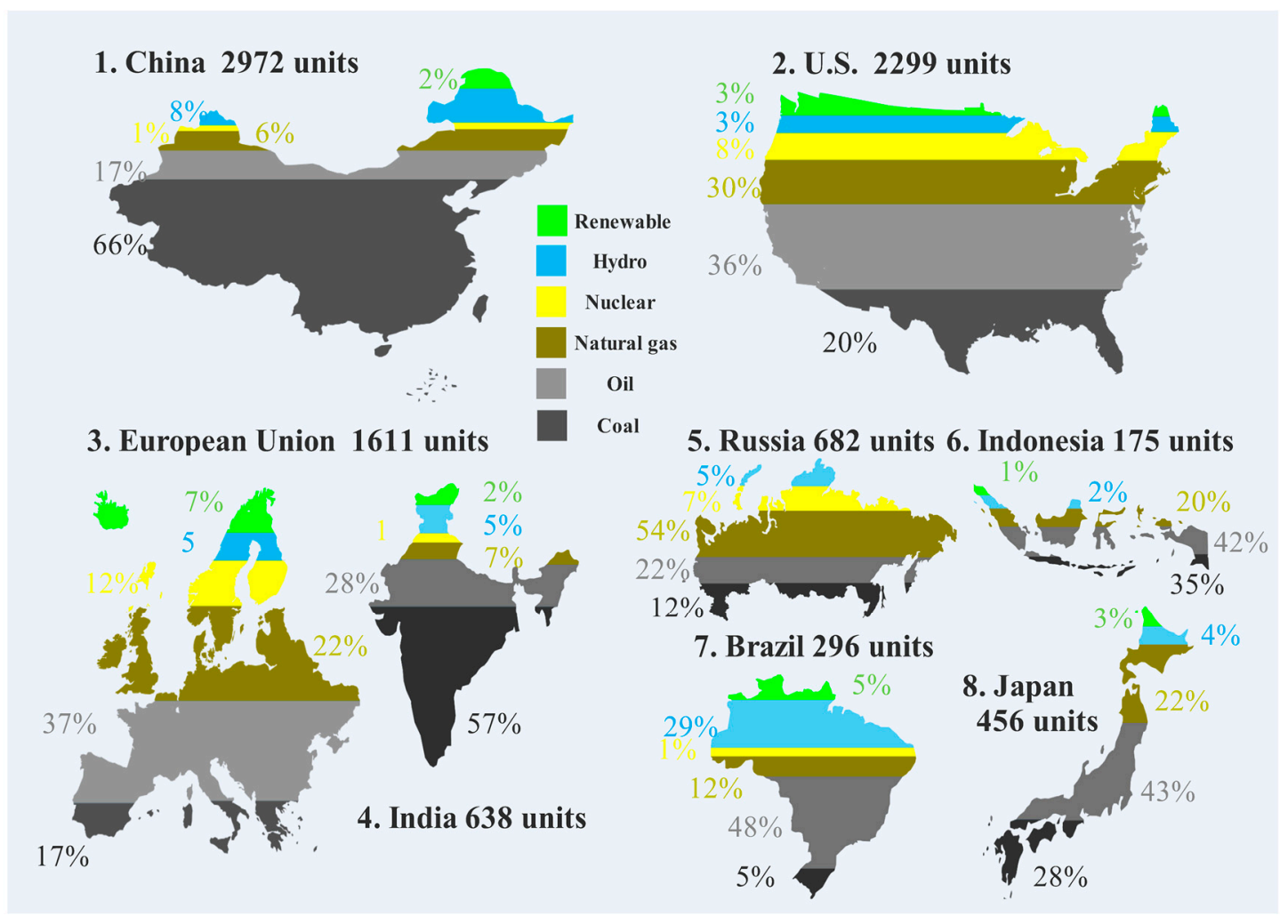

Figure 2. Energy structure of main economies in the world.

During the Asian financial crisis in 1997, the Chinese financial development had been in a downward state when the deflation occurred. After 2002, China began to decrease the deflation and growth rate of both carbon emissions and GDP. In 2008, the American subprime mortgage crisis triggered a global financial crisis, which pushed the Chinese finance into a brief recession. Therefore, at the end of 2008, China implemented a simple monetary policy and proactive fiscal policy to promote the rapid growth of energy consumption and financial development. Then the broad money supply M2 in 2013 was 11.07 billion yuan, which occupies a leading position in the world. Carbon emissions and financial development peaked from a global perspective almost simultaneously [10]. Based on the rules above, there is a high correlation between financial development and carbon emissions in China. Therefore, the influences of financial development on carbon emissions should be researched in depth.

Financial development may both stimulate the increase of carbon emissions and promote its reduction [11]. On the one hand, financial development has both a wealth and scale effects [12]. For the wealth effect, the prosperity of the financial market can allow customers to obtain wealth and capital more conveniently, which would satisfy the needs of the customers for energy consumption products and encourage them to purchase more cars, houses and so on, which would obviously increase carbon emissions. Meanwhile, the expansion of financial development and the capital market is beneficial for the expansion of the production scale of enterprises and marketing activities, which encourages the adoption of financing to build new production lines and purchase large-scale equipment to expand production. Thus, the scale effect of financial development on carbon emissions is clear.

However, financial development can also have a technological and structural effect on carbon emissions [12] because the financial development and prosperity of a capital market can attract more foreign direct investment with high technology and more investment for research and development, promoting technological advancement and curbing carbon emissions in local regions. At the same time, a developed financial market prefers investment in environmentally friendly projects, which can offer more convenient financing and motivation for new projects and facilities that have the advantages 
of energy conservation and emission reduction or market potential. Therefore, the industry and energy structure can be enhanced, and the structural effect of financial development on carbon emissions is apparent, which could promote the development of a low-carbon economy.

Based on the discussion above, in theory, the relationship between financial development and carbon emissions can be positive or negative; thus, the practical correlation needs to be analyzed more deeply and thoroughly. This paper proposes a novel method to solve this issue, which combines the establishment of an index system for financial development, the application of an extended STIRPAT model and the use of an error correction-based model based on cross-sectional independence. The main practical and theoretical significance of this paper is listed as follows:

(1) With environmental degradation and resource exhaustion, all countries face great pressure regarding carbon emissions. In total, 175 countries have signed the Paris Agreement, which is a positive and solid step towards jointly face one of the most important long-term challenges currently: climate change. As the largest carbon emitter, China's efforts to reduce carbon emissions can notably contribute to mitigating global warming. Therefore, researching carbon emissions in China is of great significance. Additionally, the influences of many factors on carbon emissions, such as urbanization and population, have been clear. However, there are mixed conclusions on how financial development affects carbon emissions due to different research approaches, selected variables and so on. In fact, with the integration of the global economy and the rapid development of the financial industry, financial development has played an increasingly pivotal role in influencing carbon emissions. Thus, this research has great practical significance.

(2) The approach of this paper in researching the relationship between carbon emissions and financial development is different from previous studies in the following aspects:

- When measuring financial development, we creatively establish a comprehensive evaluation index system to represent it instead of a single variable. To the best of our knowledge, it is impossible to fully measure financial development by using only one index, which will have an influence on the reliability of the analysis results. Additionally, giving proper weight to each individual variable in the index system plays a pivotal role in deciding the effectiveness of the system. Therefore, this paper combines a sequential global principal component analysis and the entropy weight method to ensure that the correct weight is used, which can overcome subjectivity and leverage each method fully. When calculating carbon emissions, this paper considers both the combustion of 13 types of fossil fuels and the production of cement, which can make the calculation of carbon emissions more accurate and comprehensive.

- The ARDL approach is applied to investigate the long-run relationship between financial development and carbon emissions, and a dynamic panel error-corrected model is utilized to capture the short-run impact. Before estimation, we test whether each region is independent, after which a cross-section mean group (CMG), pooled mean group (CPMG) and dynamic fixed effect (CDFE) are applied to estimate the parameters in the equation.

- The fourth feature of the proposed method is the application of the STIRPAT model. It has been proven to be effective in researching the influencing factors of carbon emissions, and one apparent advantage is that the model can be expanded to include the financial development index, apart from some common factors.

Apart from discussing the overall impact, we also divide China into different regions and stages to explore the regional and stage differences of the impact. Different from the time series data, the panel data can be more representative and effective in researching Chinese carbon emissions. Furthermore, we also discuss the impact of seven specific aspects of the financial development index system on the carbon emissions level. 
(3) Our research results not only provide the basis for policy makers in China to control carbon emissions but can also explain the relationship between financial development and carbon emissions in other developing countries in the world, such as India. Currently, financial development can facilitate carbon emissions, indicating that the wealth and scale effects are larger than the technology and structure effects. Moreover, the relationship is different in different regions and stages. With the extensive economic growth mode, financial development can lead to the increase of the carbon emissions level, and financial development will gradually show a tendency to constrain the carbon emissions level as the policies and economic structure change.

The remainder of this paper is arranged as follows: Section 2 presents a literature review. The methodology is described in Section 3, and Section 4 introduces the data and variables. Section 5 shows the empirical results. Section 6 discusses the conclusions and policy recommendations.

\section{Literature Review}

\subsection{Methods to Measure the Influencing Factors of Carbon Emissions}

Currently, main types of methods that are applied to measure the influencing factors of carbon emissions include: the factor decomposition analysis, STIRPAT model, and models based on an environmental Kuznets curve (EKC). The index decomposing analysis (IDA) is a commonly used method belonging to the factor decomposition analysis category that studies the driving factors of carbon emissions. The IDA model is inherited from the IPAT model with the index number concept for the decomposition analysis. The model needs less data and can be applied to study spatial and time series data. Several types of IDA models are available, such as the most well-known Kaya identity and the most generally applied Laspeyers index and Divisia index [13-17]. However, sectors are highly aggregated when using IDA models, which can limit policy decisions to the sectoral or product scale. Some key factors are usually ignored when using IDA models due to the limitation of data sources and model framework. Therefore, many scholars [18-21] choose to use the STIRPAT model to research the influencing factors of carbon emissions because the STIRPAT model can be expanded to incorporate additional factors; as a result, it has become well known for uncovering the impact factors of pollutant emissions [22]. The STIRPAT model is flexible for testing certain hypotheses, such as whether elasticities differ across development levels, whether a population's elasticity is different from unity and so on. If the elasticity of the population is one, the variable of population is often removed via division, so the dependent variable would be in a per capita form, and the EKC framework usually applies this form [23,24]. The essence of EKC is to determine whether there is an inverted-U shape between the economy and environment. When the environmental variable is carbon emissions per capita, EKC refers to the carbon Kuznets curves (CKC) [25-28]. Both EKC and CKC assume that pollution will show a rising trend first and then present a decreasing tendency after a certain threshold level of income is reached $[29,30]$. The CKC model is combined with energy-GDP causality by adding energy consumption as an explanatory variable to the classic CKC model. The new method is called the emission-energy-output (EEO) model [31-34]. Table 1 summarize the abovementioned literature.

\subsection{Financial Development Indexes}

The level and quality of financial development can be measured by indexes of financial development. From the appearance of the financial interrelation ratio (FIR) to the current various financial development indexes, the function and connotation of financial development have been reflected more comprehensively and clearly. Goldsmith [35] creatively developed FIR to measure the financial development level in a country or region, and it is the ratio of the market value of all financial instruments to the market value of national wealth. However, FIR is simplified, using GDP as the denominator and the total value of financial assets as the numerator. The appearance of FIR laid a foundation for follow-up studies of financial development. 
Table 1. Summary of STIRPAT model and factor decomposition analysis.

\begin{tabular}{|c|c|c|c|c|c|}
\hline Country & Year & Influencing Factors & Estimated Methods & Equation & Ref \\
\hline \multicolumn{6}{|c|}{ Factor Decomposition Model } \\
\hline EU-28 & 2000-2012 & $\begin{array}{l}\text { Level of activity, electricity intensity, electricity trade, } \\
\text { efficiency of electricity generation and fuel mix }\end{array}$ & $\begin{array}{l}\text { LMDI-I method with the use of logarithmic mean } \\
\text { weight functions }\end{array}$ & $C_{t}=A_{t} \frac{E C_{t}}{A_{t}} \frac{E P_{t}}{E C_{t}} \sum_{i} \frac{F_{i, t}}{E P_{i, t}} \frac{F_{i, t}}{F_{t}} f_{i, t}=A_{t} I_{t} T_{t} \sum_{i} e_{i, t} s_{i, t} f_{i, t}$ & {$[14]$} \\
\hline United States & $2005-2025$ & $\begin{array}{l}\mathrm{CO}_{2} \text { intensity of energy use, energy intensity of output, } \\
\text { structural change, GPD per capita, population }\end{array}$ & $\begin{array}{l}\text { Kaya identity } \\
\text { additive Logarithmic Mean Divisia Index (LMDI) } \\
\text { method }\end{array}$ & $G_{k}=\frac{G_{k}}{E_{k}} \cdot \frac{E_{k}}{Q_{k}} \cdot \frac{Q_{k}}{Q} \cdot \frac{Q}{P} \cdot P, G=\sum_{i} \frac{G_{i}}{F F E} \cdot \frac{F F E}{E} \cdot \frac{E}{Q} \cdot \frac{Q}{P} \cdot p$ & {$[15]$} \\
\hline China & 2000-2012 & $\begin{array}{l}\text { Energy structure, intensity, energy efficiency, economic } \\
\text { development, population }\end{array}$ & Logarithmic Mean Divisia Index (LMDI) method & $C^{t}=\sum_{i, j} C_{i j}^{t}=\sum_{i, j} \frac{E_{i j}^{t}}{E_{j}^{t}} \cdot \frac{C_{i j}^{t}}{E_{i j}^{t}} \cdot \frac{E_{j}^{t}}{Y_{j}^{t}} \cdot \frac{Y_{j}^{t}}{P_{j}^{t}} \cdot P_{j}^{t}=\sum S_{i j}^{t} I_{i j}^{t} F_{j}^{t} R_{j}^{t} P_{j}^{t}$ & {$[16]$} \\
\hline China & $2001-2011$ & $\begin{array}{l}\text { Energy mix change, potential energy intensity change, } \\
\text { economic activity, energy usage efficiency, energy saving } \\
\text { technology change, GDP technical efficiency, GDP } \\
\text { technology change }\end{array}$ & the multiplicative LMDI method & $C^{s}=\sum_{j} C_{j}^{s}=\sum_{j} \frac{C_{j}^{s}}{E_{j}^{s}} \times \frac{E_{j}^{s}}{E^{s}} \times \frac{E^{s}}{Y^{s}} \times Y^{s}, s \in\{0, t\}$ & {$[17]$} \\
\hline \multicolumn{6}{|c|}{ STIRPAT model } \\
\hline China & 1990-2012 & $\begin{array}{l}\text { Percentages of population employed in secondary and } \\
\text { tertiary industries, percentage of the population living in } \\
\text { urban areas, shares of the added value of secondary and } \\
\text { tertiary industry to the GDP, rural-urban income gap, } \\
\text { the cultivated land area occupied by construction }\end{array}$ & $\begin{array}{l}\text { Fixed effects (FE), the feasible generalized least } \\
\text { squares (FGLS) and the linear regression with } \\
\text { Driscoll-Kraay standard errors (DK) }\end{array}$ & $\begin{array}{c}\operatorname{Ln}\left(E C_{i t}\right)=a_{0}+a_{1} \operatorname{Ln}\left(E P 2_{i t}\right)+a_{2} \operatorname{Ln}\left(E P 3_{i t}\right)+a_{3} \operatorname{Ln}\left(U R B A_{i t}\right) \\
+a_{4} \operatorname{Ln}\left(U R I_{i t}\right)+a_{5} \operatorname{Ln}\left(I N D U_{i t}\right)+a_{6} \operatorname{Ln}\left(T E R T_{i t}\right) \\
+a_{7} \operatorname{Ln}\left(L A N D_{i t}\right)+\varepsilon_{l i t}\end{array}$ & {$[18]$} \\
\hline China & 1995-2010 & $\begin{array}{l}\text { Population, GDP per capita, tertiary industry value, } \\
\text { secondary industry output value, FDI, } \\
\text { energy consumption }\end{array}$ & $\begin{array}{l}\text { Fixed effects (FE), linear regression with } \\
\text { Newey-West standard errors (N-W), } \\
\text { panel-corrected standard errors (PCSE), and } \\
\text { Driscoll-Kraay standard errors (DK), feasible } \\
\text { generalized least squares (FGLS) }\end{array}$ & $\begin{aligned} \ln C O_{2 i t}= & a_{0}+a_{1} \ln P_{i t}+a_{2} \ln A_{i t}+a_{3} \ln T_{i t}+a_{4} \ln S_{i t} \\
& +a_{5} \ln F D I_{i t}+a_{6} \ln U R B_{i t}+e_{i t}\end{aligned}$ & {$[19]$} \\
\hline China & 1980-2010 & $\begin{array}{l}\text { Total population, urbanization level, GDP per capita, } \\
\text { technology, industrialization, service, foreign trade } \\
\text { degree, energy consumption structure }\end{array}$ & Ridge regression with biased estimates & $\begin{array}{c}\ln I=a_{0}+a_{1} \ln P_{s}+a_{2} \ln P_{c}+a_{3} \ln A+a_{4} \ln T+a_{5} \ln G+a_{6} \\
\times \ln F+a_{7} \ln W+a_{8} \ln O\end{array}$ & {$[20]$} \\
\hline China & 1990-2008 & $\begin{array}{l}\text { GDP per capita, industrial structure, population, } \\
\text { urbanization rate, technology level, energy consumption }\end{array}$ & $\begin{array}{l}\text { Partial least squares (PLS) regression, linear } \\
\text { regression }\end{array}$ & $\ln C_{t}=a+b \ln A+c \ln I S+d \ln P+m \ln R+n \ln T+e_{t}$ & {$[21]$} \\
\hline \multicolumn{6}{|c|}{ CKC/EEO model } \\
\hline Morocco & 1971-2011 & $\begin{array}{l}\text { GDP per capita, trade openness, electricity consumption } \\
\text { per capita }\end{array}$ & Vector error correction mechanism (VECM) & $\begin{array}{c}\log C O_{t}=\beta+\beta_{1} \log P C_{t}+\beta_{2} \log P C S_{t} \\
+\beta_{3} \log E C_{t}+\beta_{4} \log T R_{t}+\varepsilon_{t}\end{array}$ & {$[25]$} \\
\hline China & 2000-2013 & GDP per capita, energy intensity, urbanization level & $\begin{array}{l}\text { Semi-parametric } \\
\text { panel fixed effects regression supplemented with } \\
\text { traditional parametric regression estimation method }\end{array}$ & $\begin{aligned} \ln C E_{i j t}=\alpha_{i} & +\beta_{1} \ln A_{i t}+\beta_{2}\left(\ln A_{i t}\right)^{2}+\beta_{3} \ln E I_{i t} \\
& +\beta_{4} \ln U R_{i t}+T_{t}+\varepsilon_{i t} \\
\ln C E_{i j t}=\alpha_{i} & +\beta_{1} \ln A_{i t}+\beta_{3} \ln E I_{i t}+\beta_{4} \ln U R_{i t} \\
& +\beta_{5}\left(\ln U R_{i t}\right)^{2}+T_{t}+\varepsilon_{i t}\end{aligned}$ & {$[26]$} \\
\hline
\end{tabular}


Table 1. Cont.

\begin{tabular}{|c|c|c|c|c|c|}
\hline Country & Year & Influencing Factors & Estimated Methods & Equation & Ref. \\
\hline \multicolumn{6}{|c|}{ Factor Decomposition Model } \\
\hline Croatia & 1992-2011 & GDP & $\begin{array}{l}\text { Autoregressive distributed lag model (ARDL), } \\
\text { dynamic ordinary least squares (DOLS), fully } \\
\text { modified ordinary least squares (FMOLS) }\end{array}$ & $C O_{2 t}=\beta_{0}+\beta_{1}(G D P)_{t}+\beta_{2}(G D P S Q)_{t}+\varepsilon_{t}$ & [27] \\
\hline 164 countries & 1960-2011 & GDP per capita & Ordinary least squares (OLS) & $\ln E_{i t}=\alpha_{i}+\beta_{1 t} \ln Y_{i t}+\beta_{2 t}\left(\ln Y_{i t}\right)^{2}+\varepsilon_{i t}$ & [28] \\
\hline Korea & 1978-2007 & $\begin{array}{l}\text { Income, energy consumption, electricity production } \\
\text { (thermal power, nuclear) }\end{array}$ & $\begin{array}{l}\text { Autoregressive distributed lag model (ARDL), } \\
\text { ordinary least squares (OLS) }\end{array}$ & $\begin{aligned} \ln \left(\mathrm{CO}_{2}\right)_{t}=a_{0}+ & a_{1} \ln Y_{t}+a_{2}\left(\ln Y_{t}\right)^{2}+a_{3} \ln E N_{t} \\
& +a_{4} T H R_{t}+\varepsilon_{t} \\
\ln \left(\mathrm{CO}_{2}\right)_{t}=b_{0}+ & +b_{1} \ln Y_{t}+b_{2}\left(\ln Y_{t}\right)^{2}+b_{3} \ln E N_{t} \\
& +b_{4} N U R_{t}+\mu_{t}\end{aligned}$ & [32] \\
\hline $\begin{array}{l}\text { Southeast } \\
\text { Asian Nations }\end{array}$ & 1997-2009 & Real income per capita, energy use per capita & $\begin{array}{l}\text { Autoregressive distributed lag model (ARDL), } \\
\text { ordinary least squares (OLS) }\end{array}$ & $L E_{t}=\beta_{0}+\beta_{1} L Y_{t}+\beta_{2}\left(L Y_{t}\right)^{2}+\beta_{3} L E N_{t}+\varepsilon_{t}$ & [33] \\
\hline South Africa & 1971-2010 & Energy use, GDP per capita & $\begin{array}{l}\text { Autoregressive distributed lag model (ARDL), } \\
\text { ordinary least squares (OLS) }\end{array}$ & $y_{t}=\beta^{+} x_{t}^{+}+\beta^{-} x_{t}^{-}+u_{t}$ & [34] \\
\hline
\end{tabular}


Mckinnon [36] proposed the well-known theory of financial depth and indicated the basic indexes to measure financial depth, which is the ratio of M2 to GDP. However, the above two indexes are not appropriate for application in China owing to their limitations.

In the 1990s, new indexes were developed to represent financial development. King and Levine [37] presented Private and Privy indexes. The Private index was the ratio of credit and loans of the non-financial private sector to the total quantity of credits and loans. The Privy index was the ratio of credits and loans of the non-financial private sector to GDP. The increase of the two indexes can reflect the improvement of the efficiency of finance resource distribution. Levine and Zervos [38] developed a type of index to measure whether the stock market was active to reflect the financial development level. The method included three indexes: the capitalization rate, turnover rate and trading rate. The capitalization rate was the ratio of the total market value of stock in the stock exchange to GDP, the turnover rate was the ratio of trading volume in the domestic stock market to total market value of stock in the stock exchange, and the trading rate was the ratio of trading volume in the domestic stock market to GDP.

Next, Khan and Senhadji [39] established four simplified financial indexes based on previous studies and the International Financial Development Statistics, which are the ratio of domestic credit in non-official departments to GDP, the ratio of the sum of domestic credit in non-official departments and total market value in the stock market to GDP, the ratio of the sum of total market value in the stock market and total market value of debt in the public sector to GDP, and the ratio of the market value of stock to GDP. Additionally, Beck and Levine [40] proposed an index system to reflect the overall level of financial development and financial structure. The former included financial liveliness, financial scale, financial size and dummy variables, and the latter included structural liveness, structural scale, structural size, structural dummy variables and structural regulation.

Afterward, a large number of empirical studies have been conducted, but no pioneering indexes were proposed to measure financial development. In general, as shown in Table 2, indicators can be divided into three types. The ratio of real domestic credit to private sector per capita is an indicator that would be taken into consideration by most scholars. Foreign direct investment is also an important factor to measure financial development; however, its impact on carbon emissions is not unified. Additionally, indicators that measure the development of the stock market are also applied to reflect financial development more comprehensively. In current studies on the relationship between financial development and carbon emissions, most scholars use only one indicator to represent the overall situations of financial development, which is one-sided and lacks representativeness. Moreover, the problem of how to ensure the weight of each index is also not solved; thus, they fail to reflect the real level of financial development. In addition, simply applying the above indexes to study the impact of financial development on the carbon emissions in developing countries has major limitations. Therefore, this paper redefines the connotation of financial development and builds a scientific, systematic and comprehensive evaluation index system to represent financial development.

\subsection{Methods to Research the Relationship between Carbon Emissions and Financial Development}

A large variety of methods are applied to study the relationship between carbon emissions and financial development, including the ordinary least square-OLS [41], Johansen panel cointegration and vector error correction-based Granger causality [42,43], autoregressive distributed lag-based cointegration and Granger causality [44-48], static panel data analysis [49], dynamic panel data analysis [50,51] and heterogeneous panel data analysis [52]. A number of studies focus on cross-regional research with multiple regions and a long time period among the studies reviewed, so the dynamic panel data analysis developed by Pesaran [53] is adopted to manage such cases.

However, from the literature, it is clear that the largest challenge for the dynamic panel data model is how to select a suitable estimating technique. In general regression models, the lagged item of the dependent variable can cause an endogeneity problem, so the conventional least square regression with fixed effect or random effect will lead to bias and inconsistency of estimated coefficients. To handle 
this issue effectively and successfully, the generalized method of moment (GMM) based on difference was developed to obtain more effective estimated results. However, when estimating the regression coefficients, it is assumed that all coefficients are homogeneous and that only the constant could vary. Both methods obtain a biased estimated coefficient. In comparison, when the panel data contain a large amount of cross-sectional and time series data, the mean group (MG), pooled mean group (PMG) and dynamic fixed effect (DFE) estimated method can be adopted. The MG method allows for all coefficients and variance of errors to be heterogeneous; however, this method is easily affected by the individual abnormal value, resulting in a biased estimation. Given that, PMG was proposed to limit the fact that the long-term coefficient in the model is homogeneous and allows heterogeneous short-term coefficients and variance of errors. Compared to MG, PMG improves the efficiency of the estimation. Additionally, DFE assumes that both long-term and short-term coefficients can be homogeneous, but the intercept item can be different. The Hausman test can be adopted to further ensure which method is more suitable and whether the long-term coefficients are homogeneous [54].

\subsection{Nexus between Financial Development and Carbon Emissions}

The financial development covers a wide range of meanings, including financial depth, financial size, financial efficiency, financial openness, financial structure, financial growth and financial ecology, highly correlating with the degree of capital flows in financial institutions, capital markets, and foreign direct investment (FDI) [55]. Zhang [56] considered that the carbon emissions in a country did not necessarily depend on its income level alone; the financial development, especially for an economic entity with ever-deepening financial systems, such as China, might be another source, and the carbon emissions could be affected by upper mechanisms. To the best of our knowledge, carbon emissions are a function of the level of consumption/wealth, the energy intensity of that consumption, the energy intensity of the production of goods and services, and the carbon intensity of energy. Therefore, it is necessary to discuss how various financial measures affect those four aspects.

First, the financial development can have a direct influence on consumption level through providing residents with consumption credit services and indirectly affect the tendency and demand of their consumption. With the continuous optimization of financial structure, the financial risks become lower, so customers can plays a more positive role in the financial activities, such as investment and finance [57]. The consumption credit services and other financial products can effectively relieve liquidity constraint of income groups, improving the consumption level [58-60]. Additionally, according to the Keynes consumption function, the increase of capitals can also improve the level of consumption, and the financial institutions can change the total utility of residents through providing consumption credit services. Furthermore, financial institutions can further stimulate the consumption level through offering the support of technology and capitals to improve the ability of bearing risks and improve liquidity constraints.

Second, for consumers, on the one hand, when the financial development is improved, consumers can borrow more easily in order to purchase "large-ticket" items, thereby increasing the consumption in energy (when such items include automobiles, air conditioners and machinery) [61,62]. On the other hand, the constantly perfected institutional system and service system of finance can facilitate the green credit and research and development of low-carbon financial product innovation [63]. With the continuous optimization of financial ecology, the establishment of low-carbon products certification system and support of low-carbon products development can provide more detailed channels for carbon emissions reduction. During the progress of financial depth, the confidence of consumers and business is built, which can lead to expansion in the economy and create demand for energy intensive products [64].

Third, for companies, the development and perfect of financial system can attract more foreign investment, which could transform idle capitals into working capitals, accelerate the capital formation and accumulate creative talents (financial size); the perfected financial system can also create more financial tools and products and increase the scale of credits and securities market to reduce information 
asymmetry, increase corporate financing channels and optimize enterprises' liability structure (financial growth); the financial development can improve the investment efficiency though improving efficiency of resource allocation (financial efficiency). In a nutshell, companies can easier get access to capitals in lower costs to expand the production, which can increase the energy demand. On the contrary, the financial development can also provide capital support to encourage more companies to apply newer energy-efficient equipment to decrease energy demand. Many financial sectors can play a significant role in energy transitions. For example, the banking sector has been the main source of external finance for energy investments in most countries, with capital markets offering another alternative [65]. Capital-intensive energy production of all types can benefit from larger supplies of financial capital. When there is a larger supply of aggregate financial capital available, greater competition between capital providers helps to lower the cost of capital. If the financial capital is insufficient, some energy projects may no longer be commercially viable, due to the elevated cost of capital [66].

Finally, the carbon intensity of energy can reflect the degree of carbon-reduction technology in a region. It is supposed to expand financial openness, accelerate financial depth and improve financial efficiency to promote the technological progress, and further reduce carbon emissions. According to the analysis above, it can be known that the financial development can affect the carbon emissions through influencing the energy consumption of production and consumption, and such impact can be positive or negative. On the one hand, financial development can promote financial openness, which means that trade between nations becomes more frequent [67]. For developing countries, the rapid development of foreign trade will boost the domestic economic growth. However, most of the export products have high energy consumption and low additional value; that is, the increase of trade is at the expense of the environmental pollution. According to the pollution haven hypothesis, developed countries will regard the developing countries as the pollution haven [68]. On the other hand, the trade of new high-tech products and the service trade control can obviously lead to the carbon emissions reduction.

In general, whether the financial development increases or decreases the energy consumption depends on the sum of each effect. As shown in Table 2, the literature shows mixed results, which can be summarized as follows: Shahbaz et al. [45] and Charfeddine and Khediri [2] both proved the inverted-U shaped relationship between financial development and carbon emissions. Financial development can play a positive and significant role in combating environmental degradation in a country [69], and Jalil and Feridun [70] argued that financial development could lead to a decrease in environmental pollution. Salahuddin et al. [71], Mulali and Sab [72], Mulali and Sab [73] and Dogan and Seker [74] all supported the view that financial development was found to reduce $\mathrm{CO}_{2}$ emissions, and $\mathrm{CO}_{2}$ emissions had an impact and a positive causal relationship with financial development in the short and long run. However, Ozturk and Acaravci [75] and Abbasi and Riaz [76] held a different view, in which the financial development variable had no significant effect on per capita carbon emissions in the long run and financial development had led to the increase of $\mathrm{CO}_{2}$ emissions. Gokmenoglu et al. [77] and Boutabba [78] proved a unidirectional causality relationship between carbon emissions and financial development. Other research results focus on the impact of different indicators, such as financial openness [1,79], FDI [56,80] and the credit and stock market [11].

The mixed nature of the empirical findings investigated above can primarily be attributed to the individual researcher's selection of methods, research periods and regions, and variables [81]. Although the studies above are able to enrich our understanding of the impacts of financial development of the carbon emissions level, they have failed to offer reasonable and sufficient evidence on the inner relationship between the two aspects, a significant factor for the government in developing supporting policies for financial development and carbon emissions reduction. In addition, although scholars have conducted a considerable number of studies on the relationship between carbon emissions and financial development, they only use one or several indicators to represent financial development, which is one-sided and cannot reflect the real context of Chinese financial development. 
Table 2. Summary of studies of the relationship between financial development and carbon emissions.

\begin{tabular}{|c|c|c|c|c|c|c|}
\hline Time & Countries & Carbon Emissions & Financial Development & Method & Relationship & Ref. \\
\hline 1975-2011 & Indonesia & $\mathrm{CO}_{2}$ emission per capita & Real domestic credit to private sector per capita & Unit root/ARDL & $\begin{array}{l}\text { Financial development condenses carbon } \\
\text { emissions and inverted-U shaped relationship is } \\
\text { confirmed between financial development and } \\
\text { carbon emissions. }\end{array}$ & [45] \\
\hline 1975-2011 & UAE & $\mathrm{CO}_{2}$ emission per capita & Domestic credit to private sector & Unit root/Co-integration & $\begin{array}{l}\text { Find an inverted U-shaped relationship between } \\
\text { financial development and } \mathrm{CO}_{2} \text { emissions. }\end{array}$ & [2] \\
\hline 1971-2011 & Malaysia & $\mathrm{CO}_{2}$ emission per capita & Real domestic credit to private sector per capita & ARDL/VECM & $\begin{array}{l}\text { Financial development can play positive and } \\
\text { significant role in combating environmental } \\
\text { degradation in the country. }\end{array}$ & [69] \\
\hline 1953-2006 & China & $\mathrm{CO}_{2}$ emission per capita & $\begin{array}{l}\text { Ratio of deposit liabilities to nominal GDP, ratio } \\
\text { of credit to private sector to nominal GDP, ratio } \\
\text { of commercial bank assets to the sum of } \\
\text { commercial bank and central bank assets, foreign } \\
\text { assets plus the foreign liabilities as a share } \\
\text { of GDP }\end{array}$ & ARDL & $\begin{array}{l}\text { Financial development has led to a decrease in } \\
\text { environmental pollution. }\end{array}$ & [70] \\
\hline 1980-2012 & $\begin{array}{l}\text { Gulf Cooperation } \\
\text { Council Countries }\end{array}$ & $\mathrm{CO}_{2}$ emission per capita & $\begin{array}{l}\text { Domestic credit available to the private sector as } \\
\text { share of GDP }\end{array}$ & PVECM & $\begin{array}{l}\text { Financial development was found to reduce } \mathrm{CO}_{2} \\
\text { emissions in the long-run; Financial development } \\
\text { would continue to impact } \mathrm{CO}_{2} \text { emissions little } \\
\text { magnitude into the future. }\end{array}$ & [71] \\
\hline 1980-2008 & 19 countries & $\mathrm{CO}_{2}$ emission per capita & $\begin{array}{l}\text { Broad money, domestic credit provided by } \\
\text { banking sector, and the domestic credit to } \\
\text { private sector }\end{array}$ & Granger causality test & $\begin{array}{l}\mathrm{CO}_{2} \text { emission affected the financial development } \\
\text { based on the long run causal relationship and the } \\
\text { positive short run causal relationship. }\end{array}$ & [72] \\
\hline 1980-2008 & $\begin{array}{l}\text { Sub Saharan } \\
\text { African countries }\end{array}$ & Carbon emissions & $\begin{array}{l}\text { Broad money, the domestic credit to } \\
\text { private sector }\end{array}$ & Granger causality test & $\begin{array}{l}\mathrm{CO}_{2} \text { emission had a long run impact and a positive } \\
\text { causal relationship on the financial development. } \\
\text { The financial development indicators had a } \\
\text { positive causal relationship with the } \mathrm{CO}_{2} \text { emission. }\end{array}$ & [73] \\
\hline 1985-2011 & 40 countries & Carbon emissions & Domestic credit to private sector & EKC/PVECM & $\begin{array}{l}\text { Increases in financial development decrease } \\
\text { carbon emissions. }\end{array}$ & [74] \\
\hline 1960-2007 & Turkey & $\mathrm{CO}_{2}$ emission per capita & Domestic credit to private sector & $\begin{array}{l}\text { ARDL/Granger causality } \\
\text { test/VEC }\end{array}$ & $\begin{array}{l}\text { There is a long-run relationship between per capita } \\
\text { carbon emissions and financial development. } \\
\text { Financial development variable has no significant } \\
\text { effect on per capita carbon emissions in the } \\
\text { long run. }\end{array}$ & [75] \\
\hline 1971-2011 & Pakistan & $\mathrm{CO}_{2}$ emission per capita & $\begin{array}{l}\text { Financial intermediation development: Total } \\
\text { Credit, Private Sector Credit; Stock market } \\
\text { development: Stock market capitalization, Stocks } \\
\text { traded/turnover; Foreign direct Investment }\end{array}$ & $\mathrm{ARDL} / / \mathrm{VECM}$ & $\begin{array}{l}\mathrm{CO}_{2} \text { emission per capita is co-integrated with } \\
\text { financial development; Financial development } \\
\text { contributes to the increase of } \mathrm{CO}_{2} \text { emission; FDI } \\
\text { had a unidirectional causal relationship } \\
\text { with emissions. }\end{array}$ & [76] \\
\hline
\end{tabular}


Table 2. Cont

\begin{tabular}{|c|c|c|c|c|c|c|}
\hline Time & Countries & Carbon Emissions & Financial Development & Method & Relationship & Ref. \\
\hline 1960-2010 & Turkey & $\mathrm{CO}_{2}$ emission per capita & Real domestic credit to private sector per capita & Granger causality test & $\begin{array}{l}\text { There is a unidirectional relationship between } \\
\text { financial development and carbon emissions. }\end{array}$ & [77] \\
\hline 1971-2008 & India & Carbon emission & Domestic credit to private sector & $\begin{array}{l}\text { ARDL/Granger causality } \\
\text { test }\end{array}$ & $\begin{array}{l}\text { Financial development has a long-run positive } \\
\text { impact on carbon emissions. There is a long-run } \\
\text { unidirectional causality running from financial } \\
\text { development to carbon emissions and energy use. }\end{array}$ & [78] \\
\hline 1985-2005 & World & $\mathrm{CO}_{2}$ emission per capita & Financial openness & $\begin{array}{l}\text { EKC/Quantile regression } \\
\text { model }\end{array}$ & $\begin{array}{l}\text { More financial openness does not appear to reduce } \\
\text { the carbon emissions. }\end{array}$ & [79] \\
\hline 1965-2008 & South Africa & $\mathrm{CO}_{2}$ emission per capita & Real domestic credit to private sector per capita & Unit root/ARDL/ECM & $\begin{array}{l}\text { Banking sector development that is per capita } \\
\text { access to domestic credit of private sector help to } \\
\text { achieve lower } \mathrm{CO}_{2} \text { per capita emissions. }\end{array}$ & [1] \\
\hline 1994-2009 & China & Carbon emissions & $\begin{array}{l}\text { Financial intermediation scale, financial } \\
\text { intermediation efficiency, stock market scale, } \\
\text { stock market efficiency, foreign direct investment }\end{array}$ & $\begin{array}{l}\text { VAR/Granger causality } \\
\text { test/VECM }\end{array}$ & $\begin{array}{l}\text { The influence of financial intermediation scale is } \\
\text { the largest with weaker efficiency's influence. Stock } \\
\text { market scale has relatively larger influence on } \\
\text { carbon emissions with limited efficiency. FDI exerts } \\
\text { the least influence on the change of carbon } \\
\text { emissions. }\end{array}$ & [56] \\
\hline 1976-2009 & Vietnam & $\mathrm{CO}_{2}$ emission per capita & Real financial direct investment per capita & $\begin{array}{l}\text { Co-integration } / \text { Granger } \\
\text { causality test }\end{array}$ & $\begin{array}{l}\text { The FDI is found to be negatively affecting } \\
\mathrm{CO}_{2} \text { emissions. }\end{array}$ & [80] \\
\hline 1989-2011 & $\begin{array}{l}13 \text { European } / 12 \\
\text { Asia and Oceania }\end{array}$ & Carbon emissions & $\begin{array}{l}\text { The ratio of domestic credit to the private sector } \\
\text { to GDP, and the stock traded turnover ratio }\end{array}$ & PVAR & $\begin{array}{l}\mathrm{CO}_{2} \text { shocks on both credit and stock markets are } \\
\text { insignificant. }\end{array}$ & [11] \\
\hline
\end{tabular}


Furthermore, to simply apply these indicators to an analysis of China has great defects because they cannot represent the financial development of China properly. Therefore, this paper constructs a comprehensive index system of financial development that is in accordance with the actual Chinese context to explore its impact on carbon emissions. In addition, we also divide the comprehensive index into seven sub-aspects to study their relationship with carbon emissions. Additionally, few studies have focused on the error-correction mechanism when analyzing the long-term equilibrium relationship, so this paper applies an error correction-based dynamic panel data model to analyze the influences to overcome this issue. Furthermore, the financial development of China in different regions and stages are different; therefore, it is necessary to analyze the influences of regional financial development on carbon emissions to propose regional financial support policies to reduce carbon emissions. Thus, the research of this paper is of great innovation significance.

\section{Methodology}

\subsection{Sequential Global Principal Component Analysis (SGPCA)}

Essentially, PCA is a variant of a multivariate analysis that is based on the data analytic technique and attempts to reveal the multivariate structure of the data [82]. The purpose of this paper is to construct a new composite indicator, the financial development index (FDIN). The use of a multivariate method, such as PCA, is necessary to manage the simultaneous treatment of a series of variables [83]. PCA is performed by identifying the Eigen structure of the correlation matrix of the original data [84].

Assume that the original variables are $X_{1}, X_{2}, \ldots, X_{n}$, and the main steps of PCA are as follows:

Step 1 Z-score normalization. The first step for processing the original data is to eliminate the dimension of data. The equation is

$$
X_{i j}^{\prime}=\left(X_{i j}-\bar{X}_{i}\right) / \sigma_{i}, i=1,2, \ldots, n ; j=1,2 \ldots, P
$$

where $X_{i j}$ is the original data of the $i$ th index and $j$ th sample. $\bar{X}_{i}$ and $\sigma_{i}$ represent the mean and standard deviation of $i$ th index, respectively.

Step 2 According to the normalized data matrix $\left(X_{i j}^{\prime}\right)_{n \times p^{\prime}}$, calculate the correlation coefficient matrix $R=\left(r_{i j}\right)_{n \times n}$.

Step 3 Calculate the eigenvalue and eigenvector of $R$. The eigenvalue is calculated based on the characteristic equation $|R-\lambda I|=0$, which is the eigen-polynomial of $r_{n} \lambda^{p}+r_{n-1} \lambda^{p-1}+$ $\ldots \mathrm{r}_{1} \lambda+r_{0}=0$. Solve and order $\lambda_{1}, \lambda_{2}, \ldots, \lambda_{p}$, ranging in size:

$$
\lambda_{1} \geq \lambda_{2} \geq \ldots \lambda_{p} \geq 0
$$

List the eigenvector with regard to the eigenvalue $\lambda_{k}$.

$$
L_{k}=\left[L_{k 1}, L_{k 2}, \ldots, L_{k p}\right]^{T}, R L_{k}=\lambda L_{k}
$$

In general, when there are many variables, the Jacobi method is applied to calculate the eigenvalue and eigenvector.

Step 4 Calculate the contribution rate. The equation of the contribution rate and cumulative contribution rate is described in Equations (4) and (5) here:

$$
\lambda_{k} / \sum_{i=1}^{p} \lambda_{i}
$$




$$
\sum_{j=1}^{k}\left(\lambda_{j} / \sum_{i=1}^{p} \lambda_{i}\right)
$$

The principal component can be extracted when the cumulative contribution rate of eigenvalues $\lambda_{1}, \lambda_{2}, \ldots \lambda_{m}(m \leq p)$ is above $80 \%$.

Step 5 Calculate the principal component load matrix, which is the correlation coefficient between the principal component $Z_{k}$ and the variable $X_{i}$.

$$
p\left(Z_{k}\right)=\sqrt{\lambda_{k} L_{k}}(i=1,2, \ldots p, k=1,2, \ldots, m)
$$

Step 6 Scores of the principal component can be obtained with the following equations.

$$
\left\{\begin{array}{l}
Z_{1}=L_{11} x_{1}^{\prime}+L_{12} x_{2}^{\prime}+\ldots+L_{1 p} x_{p}^{\prime} \\
Z_{2}=L_{21} x_{2}^{\prime}+L_{22} x_{2}^{\prime}+\ldots+L_{2 p} x_{p}^{\prime} \\
\cdots \\
Z_{m}=L_{m 1} x_{m}^{\prime}+L_{m 2} x_{2}^{\prime}+\ldots+L_{m p} x_{p}^{\prime}
\end{array}\right.
$$

Based on the idea of classical PCA, this paper applies SGPCA to address the panel data. The original data are ordered according to year $T$ and region $S$, forming a $T \times S$ matrix.

\subsection{Entropy Weight Method (EWM)}

The entropy-weight method is based on Shannon entropy, originally developed by Shannon [85], which is proposed as a measure of uncertainty in information and is formulated in terms of probability theory [86]. Hence, the weights identified by entropy are also the measurement of the disorder degree of the evaluation system [87]. Entropy weight represents useful information of the evaluation index [88] and is a method that can objectively determine the weights of criteria. This method is applied in many industries, such as transport systems [89], environmental time series data [90] and so on. The specific steps of EWM are described as follows:

Step 1 Non-negative data processing. Equation (8) demonstrates that entropy is a type of calculation between the individual indicator $x_{j}$ and its corresponding $X_{i j}$, which is not related to the calculation between $x_{i}$ and $x_{j}$. Therefore, there are no dimensional differences among the data, but the procedure requires non-negativity. The data processing of the large indicator and small indicator is listed in Equations (8) and (9), respectively:

$$
\begin{aligned}
X_{i j}^{\prime} & =\frac{X_{i j}-\min \left(X_{1 j}, X_{2 j}, \ldots, X_{n j}\right)}{\max \left(X_{1 j}, X_{2 j}, \ldots, X_{n j}\right)-\min \left(X_{1 j}, X_{2 j}, \ldots, X_{n j}\right)}+1, i=1,2, \ldots, n ; j=1,2, \ldots, m \\
X_{i j}^{\prime} & =\frac{\max \left(X_{1 j}, X_{2 j}, \ldots, X_{n j}\right)-X_{i j}}{\max \left(X_{1 j}, X_{2 j}, \ldots, X_{n j}\right)-\min \left(X_{1 j}, X_{2 j}, \ldots, X_{n j}\right)}+1, i=1,2, \ldots, n ; j=1,2, \ldots, m
\end{aligned}
$$

Step 2 The proportion of the $j$ th indicator of the $i$ th scheme is

$$
f_{i j}=\frac{X_{i j}}{\sum_{i=1}^{n} X_{i j}}(j=1,2, \ldots m)
$$

Step 3 The entropy of the $j$ th indicator is:

$$
e_{j}=-k * \sum_{i=1}^{n} f_{i j} \ln \left(f_{i j}\right)
$$


where $k>0, \ln$ is the natural logarithm, $e_{j} \geq 0$. The constant $k$ is relative to the sample size $m$, and in general, $k=1 / \ln n$ and $0 \leq e \leq 1$.

Step 4 Calculate the difference coefficient of the $j$ th indicator. For the $j$ th indicator, a larger difference $g_{i}$ of indicator $X_{i j}$ plays a larger role in evaluating the case:

$$
g_{i}=1-e_{j}
$$

Step 5 The entropy weight of the $j$ th indicator is:

$$
W_{j}=\frac{g_{j}}{\sum_{j=1}^{m} g_{j}}, j=1,2 \ldots m
$$

\subsection{Combination of SGPLA and EWM}

SGPCA can use a linearly independent principal component to replace the original data structure, and the weight of the principal component can be calculated by the contribution rate of factors, which effectively avoids the influence of redundant data on the evaluation results. However, the weight of indicators is concentrated, which will conversely affect the accuracy of the results. In comparison, the single EWM also has its own shortcomings. The evaluation results sometimes disregard the importance of the indicators themselves, and the weight is notably different from the expected results. Therefore, to address the issues above, this paper combines SGPCA with EWM to adjust the weight of the indicators, making the results more objective and reliable. This successfully prevents the influences of subjective factors but can also overcome the drawbacks of single objective evaluation method. The comprehensive weight model is as follows:

$$
\alpha_{j}=\left(W_{j}+w_{j}\right) / 2
$$

where $W_{j}$ is the weight obtained by SGPCA and $w_{j}$ is the weight calculated by EWM.

\subsection{The Expanded STIRPAT Model}

The IPAT model is proposed to specify the driving forces that influence environmental pressure. In the IPAT model, $(I)$ represents the environmental impacts, which is the product of three demographic and economic factors as follows: population $(P)$, affluence $(A)$, and technology $(T)$. The IPAT model is a concise and simple way to examine the impact factors of environmental pressure, with the basic form listed in Equation (15):

$$
I=P \times A \times T
$$

Using this model as a basis, the STIRPAT model is developed. The relationship between $I, P$, $A$ and $T$ is maintained in the STIRPAT model; however, it modifies some weaknesses of the IPAT model. To be specific, it rejects the unit elasticity assumption and adds randomness for convenience in the empirical analysis. Moreover, the STIRPAT model can also be used to examine several factors, such as urbanization, industrial structure and energy structure by decomposing the population and technology terms. Due to the feasibility of the STIRPAT model, this paper utilizes the model to analyse the influence of financial development on carbon emissions by using the form of expanded STIRPAT to examine the short-term and long-term relationship. The basic form of STIRPAT is listed in Equation (16):

$$
C_{i t}=\alpha \times P_{i t}^{a} \times A_{i t}^{b} \times T_{i t}^{c} \times e_{i t}
$$

where $i$ denotes the province, $t$ represents time, $\alpha$ is a constant and $e$ is the error term. Taking the natural logarithm of both sides of Equation (16), Equation (17) can be obtained: 


$$
\operatorname{Ln}\left(C_{i t}\right)=\operatorname{Ln}(a)+b \operatorname{Ln}\left(P_{i t}\right)+c \operatorname{Ln}\left(A_{i t}\right)+d \ln \left(T_{i t}\right)+v_{i}+\varepsilon_{i t}
$$

where $v$ takes control of the province-specific fixed effects, and the new error term $\varepsilon_{i t}$ is the natural logarithm of $e$. In Equation (17), two new variables will be added, which are financial development and the square of financial development, because the current coefficients cannot reflect the relationship between financial development and carbon emissions. The introduction of the financial development aims to determine whether the influence is positive or negative, and the function of the quadratic term is to test whether the inverted-U shape exists. In this model, $P$ denotes the variable of the population (POP), $A$ is represented by GDP per capita (GDPPC), and $T$ stands for the industrial structure (IS). According to $[29,91]$, we remove population from the right-hand side and divide the dependent variable by the population. The detailed equation is shown in Equation (18):

$$
\operatorname{Ln}\left(C_{i t}\right)=\operatorname{Ln}(a)+b^{\prime} \operatorname{Ln}\left(G D P P C_{i t}\right)+c^{\prime} \operatorname{Ln}\left(I S_{i t}\right)+d^{\prime} \operatorname{Ln}\left(F_{i t}\right)+e^{\prime} \operatorname{Ln}\left(F_{i t}\right)^{2}+v_{i}+\varepsilon_{i t}
$$

In Equation (18) $C_{i t}$ denotes the carbon emissions per capita (CEPC), $F_{i t}$ measures financial development, and ${F_{i t}}^{2}$ denotes the quadratic term of financial development. In addition, in this paper, we also investigate the relationship between the carbon emissions and the seven detailed aspects of financial development: financial size (FSZ), financial structure (FST), financial openness (FOP), financial depth (FDP), financial growth (FGR), financial efficiency (FEF) and financial ecology (FEC). Thus, Equation (18) can be expanded into Equation (19) when measuring such relations:

$$
\begin{aligned}
& \operatorname{Ln}\left(C_{i t}\right)=\operatorname{Ln}(a)+b^{\prime \prime} \operatorname{Ln}\left(G D P P C_{i t}\right)+c^{\prime \prime} \ln \left(I S_{i t}\right) \\
& +d^{\prime \prime} \ln \left(F S Z_{i t}\right)+v_{i}+\varepsilon_{i t} \\
& \ldots \\
& \operatorname{Ln}\left(C_{i t}\right)=\operatorname{Ln}(a)+b^{\prime \prime} \operatorname{Ln}\left(G D P P C_{i t}\right)+c^{\prime \prime} \ln \left(I S_{i t}\right) \\
& +j^{\prime \prime} \ln \left(F E C_{i t}\right)+v_{i}+\varepsilon_{i t}
\end{aligned}
$$

\subsection{The Pooled Mean Group Estimator}

If the panel dataset is stationary, the standard panel regressions on Equation (18) can be applied to estimate effective and consistent parameters. Otherwise, a dynamic model obtained by using an auto regressive distributed lag model (ARDL) needs to be constructed for the panel data with cointegration. The developed ARDL model is a type of auto regressive model of order $p$ in the dependent variable $C$, and the form is ARDL $(p ; q, q, q, q)$, as shown in Equation (20):

$$
\begin{gathered}
\operatorname{Ln}\left(C_{i t}\right)=\operatorname{Ln}(a)+\sum_{j=1}^{p} \lambda_{i j} \operatorname{Ln}\left(C_{i, t-j}\right)+\sum_{j=1}^{q} b_{i j}^{\prime} \operatorname{Ln}\left(G D P P C_{i, t-1}\right) \\
+\sum_{j=1}^{q} c_{i j}^{\prime} \operatorname{Ln}\left(I S_{i, t-1}\right)+\sum_{j=1}^{q} d_{i j}^{\prime} \operatorname{Ln}\left(F_{i, t-1}\right)+\sum_{j=1}^{q} e_{i j}^{\prime} \operatorname{Ln}\left(F_{i, t-1}\right)^{2}+v_{i}+\varepsilon_{i t}
\end{gathered}
$$

Equation (21) is transformed into a panel error-correction model to enhance the efficiency and is a PMG form. The PMG approach dictates that in estimating the long-run effects and the speed of adjustments to the long run, we must allow the short-run dynamics to be determined for each country. The PMG estimators are consistent and efficient even in the presence of endogenous and non-stationary regressors, which is described in Equation (21):

$$
\begin{aligned}
& \Delta \operatorname{Ln}\left(C_{i t}\right)=\phi_{i}\left[\operatorname{Ln}\left(C_{i, t-1}\right)-b_{i}^{\phi} \operatorname{Ln}\left(G D P P C_{i, t}\right)-c_{i}^{\phi} \operatorname{Ln}\left(I S_{i, t}\right)-d_{i}^{\phi} \operatorname{Ln}\left(F_{i, t}\right)\right. \\
& \left.-e_{i}^{\phi} \operatorname{Ln}\left(F_{i, t}\right)^{2}\right]+\sum_{j=1}^{p-1} \lambda_{i j}^{*} \Delta \operatorname{Ln}\left(C_{i, t-j}\right)+\sum_{j=0}^{q-1} b_{i j}^{*} \Delta \operatorname{Ln}\left(G D P P C_{i, t-j}\right) \\
& +\sum_{j=0}^{q-1} c_{i j}^{*} \Delta \operatorname{Ln}\left(I S_{i, t-j}\right)+\sum_{j=0}^{q-1} d_{i j}^{*} \Delta \operatorname{Ln}\left(F_{i, t-j}\right)+\sum_{j=0}^{q-1} e_{i j}^{*} \Delta \operatorname{Ln}\left(F_{i, t-j}\right)^{2}+v_{i}+\varepsilon_{i t}
\end{aligned}
$$


where $\phi_{i}=\sum_{j=1}^{p} \lambda_{i j}-1, \lambda_{i j}^{*}=-\sum_{m=j+1}^{p} \lambda_{i m}, a_{i}^{\phi}=-\sum_{j=0}^{q} a_{i j}^{\prime} / \phi_{i}, b_{i}^{\phi}=-\sum_{j=0}^{q} b_{i j}^{\prime} / \phi_{i}, c_{i}^{\phi}=-\sum_{j=0}^{q} c_{i j}^{\prime} / \phi_{i}, d_{i}^{\phi}=$ $-\sum_{j=0}^{q} d_{i j}^{\prime} / \phi_{i}, e_{i}^{\phi}=-\sum_{j=0}^{q} e_{i j}^{\prime} / \phi_{i}, a_{i}^{*}=-\sum_{m=j+1}^{p} a_{i m^{\prime}}^{\prime} b_{i}^{*}=-\sum_{m=j+1}^{p} b_{i m^{\prime}}^{\prime} c_{i}^{*}=-\sum_{m=j+1}^{p} c_{i m}^{\prime}, d_{i}^{*}=-\sum_{m=j+1}^{p} d_{i m}^{\prime}$, $e_{i}^{*}=-\sum_{m=j+1}^{p} e_{i m}^{\prime}$.

In Equation (21), $\phi_{i}$ is the error-correcting speed of adjustment, and with a significantly negative value, the impacts of the independent variables are cointegrated. That is, the long-run mean reversion exists. The long- run influences are represented by $a^{\phi}, b^{\phi}, c^{\phi}, d^{\phi}$ and $e^{\phi}$, respectively. Accordingly, the short-run impact is captured by $a^{*}, b^{*}, c^{*}, d^{*}$ and $e^{*}$.

Based on Binder and Offermanns [92], Equation (21) can be respecified to correct for the cross-sectionally correlated errors as follows:

$$
\begin{aligned}
& \Delta \operatorname{Ln}\left(C_{i t}\right)=\phi_{i}\left[\operatorname{Ln}\left(C_{i, t-1}\right)-b_{i}^{\phi} \operatorname{Ln}\left(G D P P C_{i, t}\right)-c_{i}^{\phi} \operatorname{Ln}\left(I S_{i, t}\right)-d_{i}^{\phi} \operatorname{Ln}\left(F_{i, t}\right)-e_{i}^{\phi} \operatorname{Ln}\left(F_{i, t}\right)^{2}\right] \\
& +\sum_{j=1}^{q-1} \lambda_{i j}^{*} \Delta \operatorname{Ln}\left(C_{i, t-j}\right)+\sum_{j=1}^{q-1} b_{i j}^{*} \Delta \operatorname{Ln}\left(G D P P C_{i, t-j}\right)+\sum_{j=1}^{q-1} c_{i j}^{*} \Delta \operatorname{Ln}\left(I S_{i, t-j}\right)+\sum_{j=1} d_{i j}^{*} \Delta \operatorname{Ln}\left(F_{i, t-j}\right) \\
& +\sum_{j=1}^{q-1} e_{i j}^{*} \Delta \operatorname{Ln}\left(F_{i, t-j}\right)^{2}+\sum_{j=1}^{p-1} \overline{\lambda_{i j}^{\gamma} \Delta \operatorname{Ln}\left(C_{i, t-j}\right)}+\sum_{j=1}^{q-1} \overline{b_{i j}^{*} \Delta \operatorname{Ln}\left(G D P P C_{i, t-j}\right)}+\sum_{j=1}^{q-1} \overline{c_{i j}^{*} \Delta \operatorname{Ln}\left(I S_{i, t-j}\right)} \\
& +\sum_{j=1}^{q-1} \overline{d_{i j}^{*} \Delta \operatorname{Ln}\left(F_{i, t-j}\right)}+\sum_{j=1}^{q-1} \overline{e_{i j}^{*} \Delta \operatorname{Ln}\left(F_{i, t-j}\right)^{2}}+v_{i}+\varepsilon_{i t}
\end{aligned}
$$

where $\quad \sum_{j=1}^{p-1} \overline{\lambda_{i j}^{\gamma} \Delta \operatorname{Ln}\left(C_{i, t-j}\right)}, \quad \sum_{j=1}^{p-1} \overline{b_{i j}^{\gamma} \Delta \operatorname{Ln}\left(U R_{i, t-j}\right)}, \quad \sum_{j=1}^{p-1} \overline{c_{i j}^{\gamma} \Delta \operatorname{Ln}\left(I S_{i, t-j}\right)}, \quad \sum_{j=1}^{p-1} \overline{d_{i j}^{\gamma} \Delta \operatorname{Ln}\left(F_{i, t-j}\right)} \quad$ and $\sum_{j=1}^{p-1} \overline{e_{i j}^{\gamma} \Delta \operatorname{Ln}\left(F_{i, t-j}\right)^{2}}$ are the cross-sectional average.

\section{Data and Variables}

The research aimed to study the relationship between financial development (FD) and carbon emissions level (CEL) based on a regional analysis by applying the panel data, so we collected data covering 30 provinces in China from 2000 to 2013, considering the data availability. A detailed calculation of the variables is introduced in this section.

\subsection{Calculation of Carbon Emissions in Each Province}

Currently, fossil fuel combustion and the production of cement are two main sources for carbon emissions in China, so when calculating carbon emissions, this paper considers these two aspects. The most commonly used fossil fuels in China are coal, oil and natural gas, which results in a proportion of $66 \%, 17.1 \%$ and $5.7 \%$, respectively, in total energy consumption; thus, this paper chooses the terminal consumption values of 13 types of main fossil fuels to calculate the cumulative carbon emissions to enhance the accuracy of data, including raw coal, cleaned coal, other washed coal, briquettes, coke, crude oil, gasoline, kerosene, diesel oil, fuel oil, liquefied petroleum gas, refinery gas and natural gas. The detailed calculation equation is described as follows:

$$
C_{i t f}=\sum_{j=1}^{13} C_{i t j}=\sum_{j=1}^{13} M_{i t j} \times K_{j} \times q_{j}
$$

where $M_{i t j}$ represents the physical quantity of the $j$ th fossil fuel in the $i$ th province in the $t$ th year. $K_{j}$ denotes the standard coal efficiency, which can be found in the China Statistical Yearbook (2014) [93], and $q_{j}$ is the carbon emissions coefficient published by IPCC in 2006 [94]. Assuming that the utilization 
efficiency of fossil fuels is unchanged in the short term, the carbon emissions coefficient of each fossil fuel is constant.

The level of carbon emissions during the cement production process is also taken into consideration. The calculation is shown in Equation (24):

$$
C_{i t c}=N_{i t} \times a
$$

where $N_{i t}$ represents the physical quantity of cement in the $i$ th province in the $t$ th year, and $a$ is the carbon emissions factor, which is 0.5272 [95]. The data of the cement output in each province of China are collected from the CEinet Statistics Database [96].

\subsection{Financial Development Index System (FDIS)}

Financial development covers a wide range, and it is a challenging and difficult task to measure it accurately. We need to build a comprehensive and scientific index system to describe the regional financial development of China.

As discussed above, financial development has been measured by using different types of indexes without a unified standard, which will cause measuring errors and influence the reliability of the research results. Specifically, this is why people sometimes obtain completely different conclusions when studying the relationship between FD and CEL. Therefore, this paper constructs an innovative financial development index system to overcome the limitations mentioned above. According to the conception of financial development and existing literature, financial development includes the following seven aspects: financial size, financial structure, financial openness, financial depth, financial growth, financial efficiency and financial ecology. The measurement of each indicator is shown in Table 3. The data are obtained from the China Statistical Yearbook (2001-2014), the Statistical Yearbook of each province of China (2001-2014) and the Almanac of China's Finance and Banking (2001-2014), respectively.

Table 3. Summary of seven specific aspects of the financial development.

\begin{tabular}{|c|c|c|}
\hline Criteria Level & Factor Level & Measuring Level \\
\hline \multirow{3}{*}{ FSZ } & Financial asset & $\begin{array}{l}\mathrm{X}_{1} \text { : Gross of banking assets, Security assets and Premium } \\
\text { income }\end{array}$ \\
\hline & Financial institutions & $\mathrm{X}_{2}:$ Number of insurance and Security institutions \\
\hline & Financial professionals & $\mathrm{X}_{3}:$ Total number of financial professionals \\
\hline \multirow{2}{*}{ FST } & Financial industrial structure & $\mathrm{X}_{4}$ : Banking assets/Financial assets \\
\hline & Internal structure of banking industry & $X_{5}:$ Deposit/Loan \\
\hline \multirow{2}{*}{ FOP } & Capital flow liberalization & $\mathrm{X}_{6}:$ FDI/Total investment in fixed assets \\
\hline & Localization of foreign financial service & $\mathrm{X}_{7}$ : Gross of FDI in financial industry \\
\hline \multirow{3}{*}{ FDP } & Finacialization & $\mathrm{X}_{8}:$ Gross of deposit and loan of financial institutes/GDP \\
\hline & Financial depth rate & $\mathrm{X}_{9}:$ Financial assets/GDP \\
\hline & Foreign direct investment depth rate & $\mathrm{X}_{10}: \mathrm{FDI} / \mathrm{GDP}$ \\
\hline \multirow{4}{*}{ FGR } & Financial increasing & $\begin{array}{l}\mathrm{X}_{11} \text { : Increasing speed of RMB deposit of financial institutions } \\
\mathrm{X}_{12} \text { : Increasing rate of } \mathrm{RMB} \text { deposit of residents }\end{array}$ \\
\hline & Capital formation speed & $X_{13}:$ Gross capital formation/GDP \\
\hline & Insurance density & $\mathrm{X}_{14}:$ Premium per capita \\
\hline & Insurance depth & $\mathrm{X}_{15}$ : Premium income/GDP \\
\hline \multirow{3}{*}{ FEF } & Macroscopic allocation efficiency & $\begin{array}{l}\mathrm{X}_{16} \text { : Transform rate of saving to investment } \\
\mathrm{X}_{17} \text { : Capital formation rate }\end{array}$ \\
\hline & Saving rate & $\mathrm{X}_{18}:$ Saving/Disposal personal income \\
\hline & Marginal productivity of capital & $\mathrm{X}_{19}$ : GDP growth/Total fixed asset investment \\
\hline \multirow{3}{*}{ FEC } & Institutional environment & $\mathrm{X}_{20}$ : Variety of distribution \\
\hline & Intermediary services & $\mathrm{X}_{21}$ : Rate of patent authorization and pending \\
\hline & Social credit system & $\mathrm{X}_{22}$ : Individual credit \\
\hline
\end{tabular}

According to the methods of SGPCA and EWM, the FDIS is established. The integrated weight of each indicator in FDIS is listed in Appendix B, Table A2. 


\subsection{Other Variables}

Table 4 shows two control variables, and the data are collected from the China Statistical Yearbook (2001-2014) and China Industrial Economic Statistical Yearbook (2001-2014).

Table 4. List of other variables.

\begin{tabular}{ccccc}
\hline Name & Variable Measure & Symbol & Expected Sign & \multicolumn{1}{c}{ Economic Implications } \\
GDP per capita & $\begin{array}{l}\text { GDP/total } \\
\text { population }\end{array}$ & GDPPC & $+/-$ & $\begin{array}{l}\text { The influence is uncertain. According to EKC, } \\
\text { carbon emissions would increase first with the rise } \\
\text { of GDP per capita and then show a declining trend } \\
\text { after a certain threshold value is reached. }\end{array}$ \\
\hline Industrial structure & $\begin{array}{c}\text { Total industrial } \\
\text { output value/GDP }\end{array}$ & IS & $\begin{array}{l}\text { The process of industrialization includes } \\
\text { technological advancement, which can redistribute } \\
\text { the production factors and improve the production } \\
\text { efficiency. However, in the early stages of } \\
\text { industrialization, the carbon emissions will increase. }\end{array}$ \\
\hline
\end{tabular}

Notes: (1) + indicates that the impact is positive; (2) - indicates that the impact is negative.

\section{Empirical Results and Discussion}

\subsection{Current Situations of Carbon Emissions and Financial Development}

The clustering method is applied to divide all 30 provinces into four categories as follows: high emission-high development (HE-HD), high emission-low development (HE-LD), low emission-high development (LE-HD) and low emission-low development (LE-LD).

\subsubsection{Current Situations of Carbon Emissions in China}

From Figure 3I, it can be seen that the carbon emissions of Shandong, Hebei, Shanxi, Henan and Jiangsu dominate the top positions, while the carbon emissions of Qinghai and Hainan are low. Shandong and Shanxi are major provinces that produce coal, and the proportion of coal consumption occupies a large share; thus, the carbon emissions of the two provinces account for nearly $18 \%$ of the entire country.

(I) The average of total carbon emission from 2000 to 2013

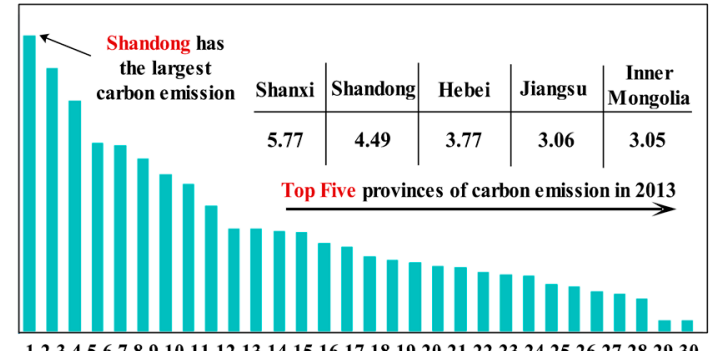

123456789101112131415161718192021222324252627282930

(III) The average of carbon emission per capita from 2000 to 2013

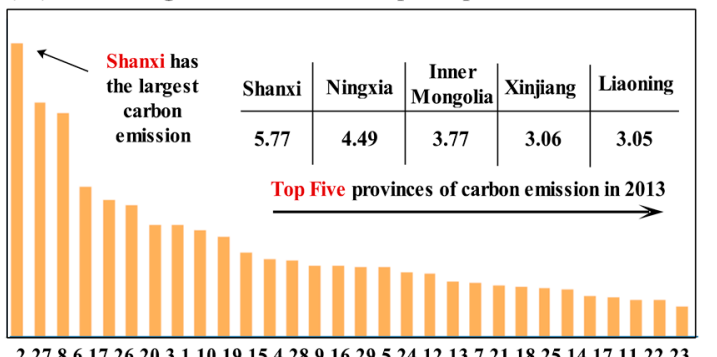

(II) The average of carbon emission intensity from 2000 to 2013

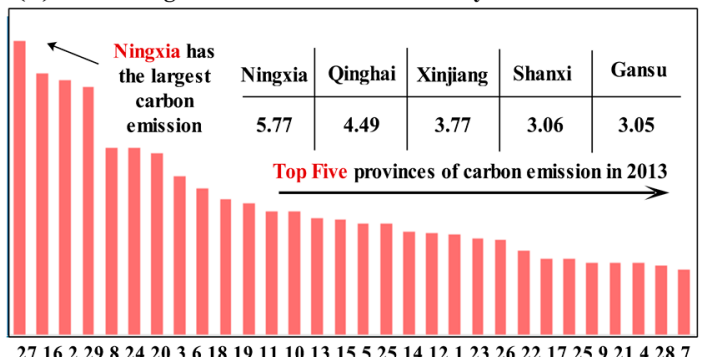

(IV) The numbers representing each province of China

\begin{tabular}{|cccccccc}
\hline No. & Province & No. & Province & No. & Province & No. & Province \\
\hline 1 & Shandong & 9 & Zhejiang & 17 & Shanghai & 25 & Chongqing \\
2 & Shanxi & 10 & Heilongjiang & 18 & Yunnan & 26 & Tianjin \\
3 & Hebei & 11 & Sichuan & 19 & Jilin & 27 & Ningxia \\
4 & Jiangsu & 12 & Anhui & 20 & Xinjiang & 28 & Beijing \\
\hline 5 & Henan & 13 & Hubei & 21 & Fujian & 29 & Qinghai \\
6 & Liaoning & 14 & Hunan & 22 & Jiangxi & 30 & Hainan \\
7 & Guangdong & 15 & Shaanxi & 23 & Guangxi & & \\
8 & Inner & 16 & Guizhou & 24 & Gansu & & \\
\hline
\end{tabular}

Figure 3. Current situations of carbon emissions level. 
Figure 3II demonstrates that the carbon emissions intensity (CEI) of Ningxia is nearly three times larger than that of Guangdong. We can conclude that the carbon emissions are related to the economic aggregate, but there is no relationship between CEI and economic aggregate. Instead, CEI is related to the economic development stage and industrial development level.

Figure 3III shows the changing trend of CEPC. Apart from Shanxi, whose CEPC ranks first in China and is approximately 9.6 times that of Guangxi, the order of the other provinces changes greatly. The result reflects the phenomenon that carbon emissions and energy consumption tend to be centralized in cities where population density is high. Therefore, each large- and middle-scale city has a high potential for reducing carbon dioxide.

\subsubsection{Current Situations of Financial Development in China}

Beijing, Shanghai and Guangdong are provinces with the most sophisticated financial development, while Guizhou, Qinghai and Guangxi have the lowest financial development level. According to Figure 4IV, it can be seen that in addition to the top three provinces, the change of financial development in the other provinces is obvious and large. What is worth noticing is that the financial development of Liaoning ranks 3rd; however, in 2010, it ranked 23rd, which reflects a declining tendency. Additionally, the provinces in the north-eastern regions have less developed financial development. In comparison, coastal regions, such as Guangdong, Shanghai and Zhejiang, have strong financial power. Furthermore, the financial development of the western region, including Ningxia and Xinjiang, exhibits a great increasing potential.

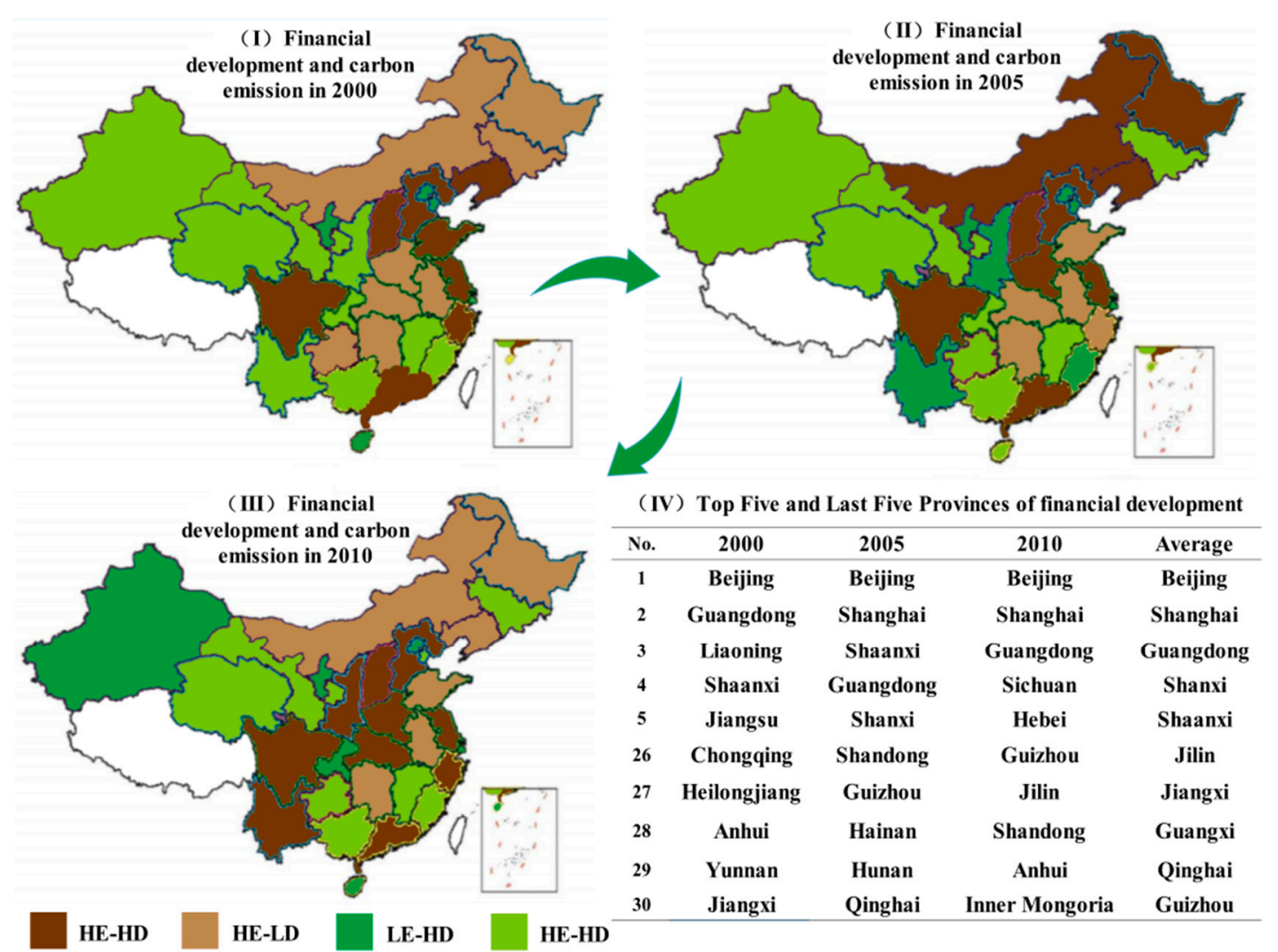

Figure 4. Financial development and cluster results of each province.

\subsubsection{Results of the Clustering Analysis}

According to the results calculated above, we can rank each province from 1 to 30. Carbon emissions is the $x$-axis, and financial development is the $y$-axis. If the Euclidean distance between a 
province and the point at the bottom left corner is shorter than the other three corners, this indicates that the province belongs to the HE-HE category. Therefore, the initial clustering points are Beijing (LE-HD), Shanxi (HE-HD), Shandong (HE-LD) and Qinghai (LE-LD). The LE-HD category presents two extremes: financial development in Beijing and Shanghai is advanced; financial development in Xinjiang and Hainan is less advanced.

With respect to the different years, the changing rule can be calculated as shown in Figure 4 . LE-HD can be regarded as the most ideal development mode, and the results show that Shanghai, Xinjiang and Chongqing shift from HE-HD to LE-HD due to the improvement of the production and utilization efficiency. The HE-LD mode is the least ideal. Both Liaoning and Shandong transfer from HE-HD to HE-LD, reflecting problems during the process of financial development. From the perspective of carbon emissions, Shanxi shifts from LE-HD to HE-HD, indicating that the financial development of Shanxi has been at a high level but at the expense of the environment. Although the HE mode can meet the requirements of sustainable development, it cannot be proven that LE is sustainable. Therefore, provinces should adopt effective measures to reduce carbon emissions while promoting economic development.

\subsection{Impact of Financial Development on Carbon Emissions}

The results of cross-sectional dependence (CD), panel unit root test and panel cointegration tests are shown in Appendix C. This section will discuss the impact of financial development on the CEL in detail.

\subsubsection{The Overall Impact}

Table 5 shows that the long-term adjustment coefficient of the error correction model is negative, which is in accordance with the principle of reverse correction. Additionally, the CDFE model passes the significance test at the $1 \%$ level, which also proves the rationality of the model. In general, the results in Table 5 demonstrate that financial development will promote CEL. A detailed analysis is as follows:

(1) For the long-term impact, the coefficients of financial development on CEPC are 0.291, which is statistically significant. Additionally, the coefficient of $\mathrm{FD}^{2}$ is negative, which is -0.321 , proving the inverted U-shape relationship between financial development and CEPC in China. The results indicate that, at the present stage, the development of finance is at the expense of the environment.

(2) Compared with long-term influence, the short-term coefficient of FD on the CEPC is 0.375. The results show that the short-term influence degree is larger than the long-term impact; therefore, the inhibiting effect of the FD on CEL requires a long time to be realized. This conclusion is valuable because it suggests that policy makers consider the long-term influence when developing policies.

(3) Finally, for the overall impact of other variables, the GDPPC can facilitate CEPC. The industrial structure contributes to CEPC with a coefficient of 0.310 . The results fully reflect the characteristics of high output value and low production efficiency during the industrialization process. 
Table 5. Results of overall impact of FD on CEL.

\begin{tabular}{|c|c|c|c|c|c|c|c|}
\hline & \multicolumn{3}{|c|}{ Long-Run Coefficients } & & \multicolumn{3}{|c|}{ Short-Run Coefficients } \\
\hline & CMG & CPMG & CDFE & & CMG & CPMG & CDFE \\
\hline GDPPC & $\begin{array}{c}0.228 \\
(0.452)\end{array}$ & $\begin{array}{c}0.214^{* * *} \\
(3.251)\end{array}$ & $\begin{array}{c}0.293^{* * *} \\
(7.320)\end{array}$ & GDPPC & $\begin{array}{l}-0.491 \\
(-0.273)\end{array}$ & $\begin{array}{c}0.293 \\
(1.193)\end{array}$ & $\begin{array}{c}0.312 \\
(0.685)\end{array}$ \\
\hline IS & $\begin{array}{l}-1.393 * * \\
(-1.982)\end{array}$ & $\begin{array}{c}0.344^{* * *} \\
(5.619)\end{array}$ & $\begin{array}{l}0.310 * * \\
(2.020)\end{array}$ & IS & $\begin{array}{l}0.219 * \\
(1.920)\end{array}$ & $\begin{array}{l}0.174 * * \\
(2.327)\end{array}$ & $\begin{array}{c}-0.258 \\
(-0.531)\end{array}$ \\
\hline FD & $\begin{array}{c}-0.729 \\
(-0.308)\end{array}$ & $\begin{array}{l}0.986 * \\
(1.830)\end{array}$ & $\begin{array}{c}0.291 * * * \\
(8.792)\end{array}$ & FD & $\begin{array}{c}0.154 \\
(0.983)\end{array}$ & $\begin{array}{c}-0.215^{* * *} \\
(-7.170)\end{array}$ & $\begin{array}{l}0.375^{* *} \\
(2.290)\end{array}$ \\
\hline $\mathrm{FD}^{2}$ & $\begin{array}{c}2.175 \\
(0.835)\end{array}$ & $\begin{array}{c}0.252 * * * \\
(3.714)\end{array}$ & $\begin{array}{c}-0.321^{* * *} \\
(-4.832)\end{array}$ & $\mathrm{FD}^{2}$ & $\begin{array}{l}-0.352 \\
(-0.159)\end{array}$ & $\begin{array}{c}0.719 \\
(1.024)\end{array}$ & $\begin{array}{c}0.907 \\
(0.925) \\
\end{array}$ \\
\hline Error correction & $\begin{array}{l}-0.286 * \\
(-1.992)\end{array}$ & $\begin{array}{l}-0.491 * * \\
(-2.218)\end{array}$ & $\begin{array}{c}-0.219 * * * \\
(-3.890)\end{array}$ & Constant & $\begin{array}{c}0.912 \\
(0.014)\end{array}$ & $\begin{array}{c}2.566^{* * *} \\
(4.376)\end{array}$ & $\begin{array}{c}4.474 * * * \\
(4.140)\end{array}$ \\
\hline Number of obs & & 390 & & & 1 & & $\geq 1.000$ \\
\hline Number of groups & & 30 & & Hausman test & 2 & & $\geq 0.989$ \\
\hline Log Likelihood & & 881.343 & & & 3 & & $\geq 1.000$ \\
\hline
\end{tabular}

\subsubsection{The Impact on Different Regions}

China is a vast territory with different financial development levels, levels of GDP per capita and industrial structures among the eastern, middle, western and north-eastern regions. The difference in each area is complicated and distinctive. To explore the regional difference, China is divided into four regions as shown in Appendix D, Table A6 [64]. The number that represents each province is shown in Figure 3IV. The results of Table 6 are analysed as follows:

(1) Eastern region. FD constrains CEL in the long term. That is, if the financial development increases $1 \%$, CEPC decreases $0.374 \%$. Meanwhile, the coefficient of $\mathrm{FD}^{2}$ is both negative and significant, indicating an inverted U-shape relationship between financial development and CEL [97]. Financial development in the eastern region tends to be mature, so it can constrain CEL. GDPPC can cause carbon emissions to increase, leading to a rise of energy consumption and demand. The results of other variables fully prove that the industrial process of the eastern region contains technological advancement and improvements in production efficiency, which are caused by the factor reallocation [19].

(2) Middle region. The impact is statistically significant at the $1 \%$ level with positive coefficients of 0.391. The GDPPC increases CEPC with a coefficient of 0.326. The industrial structure has a significant and positive impact on CEL. In the short term, the coefficient is larger, indicating that the middle region needs time to achieve the carbon emissions reduction.

(3) Western region. The long-term coefficient of FD on CEL in western region is negative and significant, but the absolute value, 0.461 , is larger than the middle region. Thus, with the improvement of the financial development level, carbon emissions will increase at a greater magnitude than the middle region. The GDPPC can affect the carbon emissions level positively at the $1 \%$ level. The western region is in a start-up stage, and the region needs to improve the investment environment, increase openings, attract social capital and participate actively in western development and establishment.

(4) North-eastern region. The influence is positive and significant and exceeds the middle region at a value of 0.698 . The influence of other variables is similar to that in the western region. In the short term, the impact of FD on CEPC is 0.429 . As a traditional industrial base, the north-eastern region has an extensive economic development pattern. The accumulated deep contradiction is gradually becoming obvious, causing low utilization efficiency in each resource and condition. Financial development proceeds at the cost of environment. 
Table 6. Results of impact in difference regions.

\begin{tabular}{|c|c|c|c|c|c|c|c|c|c|c|c|c|c|}
\hline & & \multicolumn{3}{|c|}{ Eastern Region } & \multicolumn{3}{|c|}{ Middle Region } & \multicolumn{3}{|c|}{ Western Region } & \multicolumn{3}{|c|}{ Northeastern Region } \\
\hline & & CMG & CPMG & CDFE & CMG & CPMG & CDFE & CMG & CPMG & CDFE & CMG & CPMG & CDFE \\
\hline \multirow{4}{*}{$\begin{array}{l}\text { Long-run } \\
\text { coefficients }\end{array}$} & GDPPC & $\begin{array}{c}0.347^{*} \\
(-1.832)\end{array}$ & $\begin{array}{l}0.314^{* *} \\
(2.130)\end{array}$ & $\begin{array}{c}0.224^{* * * *} \\
(3.261)\end{array}$ & $\begin{array}{l}0.329 * \\
(1.922)\end{array}$ & $\begin{array}{c}-0.131 \\
(-0.840)\end{array}$ & $\begin{array}{l}0.326^{* *} \\
(2.281)\end{array}$ & $\begin{array}{l}0.318^{* *} \\
(2.175)\end{array}$ & $\begin{array}{c}0.205^{* * * *} \\
(4.435)\end{array}$ & $\begin{array}{c}0.342 * * * \\
(7.123)\end{array}$ & $\begin{array}{c}-0.279 * * * \\
(-4.328)\end{array}$ & $\begin{array}{l}-0.273^{* *} \\
(-2.251)\end{array}$ & $\begin{array}{c}-0.125 * * * * \\
(6.764)\end{array}$ \\
\hline & IS & $\begin{array}{l}-0.358 * * \\
(-6.486)\end{array}$ & $\begin{array}{l}-0.208^{*} \\
(-1.945)\end{array}$ & $\begin{array}{l}-0.352 * * \\
(-2.471)\end{array}$ & $\begin{array}{l}0.246^{* * *} \\
(2.929)\end{array}$ & $\begin{array}{l}-0.253 * \\
(-1.842)\end{array}$ & $\begin{array}{c}0.510 \\
(0.529)\end{array}$ & $\begin{array}{l}0.353 * * \\
(2.334)\end{array}$ & $\begin{array}{c}0.411 \\
(1.150)\end{array}$ & $\begin{array}{c}0.261 * * * \\
(4.205)\end{array}$ & $\begin{array}{l}0.622 * * \\
(2.335)\end{array}$ & $\begin{array}{c}0.832 * \\
(1.8192)\end{array}$ & $\begin{array}{c}0.741 * * * * \\
(3.935)\end{array}$ \\
\hline & FD & $\begin{array}{l}-0.335 * \\
(-1.920)\end{array}$ & $\begin{array}{c}0.427 \\
(1.207)\end{array}$ & $\begin{array}{c}-0.374 * * * \\
(-3.238)\end{array}$ & $\begin{array}{c}0.521^{* * * *} \\
(4.837)\end{array}$ & $\begin{array}{c}-0.581 \\
(-1.428)\end{array}$ & $\begin{array}{c}0.391 * * * \\
(4.519)\end{array}$ & $\begin{array}{l}0.613^{* * *} \\
(2.029)\end{array}$ & $\begin{array}{l}0.426^{*} \\
(1.992)\end{array}$ & $\begin{array}{c}0.461^{* * * *} \\
(4.298)\end{array}$ & $\begin{array}{l}0.633^{*} \\
(1.826)\end{array}$ & $\begin{array}{c}0.741 * * * \\
(3.514)\end{array}$ & $\begin{array}{l}0.698 \text { ** } \\
(2.279)\end{array}$ \\
\hline & $\mathrm{FD}^{2}$ & $\begin{array}{l}-0.348 * * \\
(-2.205)\end{array}$ & $\begin{array}{l}-0.359 * * \\
(-2.275)\end{array}$ & $\begin{array}{c}-0.258^{* * *} \\
(-5.324)\end{array}$ & $\begin{array}{c}-0.762 * * * \\
(-4.732)\end{array}$ & $\begin{array}{l}0.164^{*} \\
(1.938)\end{array}$ & $\begin{array}{l}-0.873 * * \\
(-2.134)\end{array}$ & $\begin{array}{l}-0.523 * * \\
(-2.490)\end{array}$ & $\begin{array}{l}-0.741 \\
(-0.148)\end{array}$ & $\begin{array}{c}-0.915^{* * *} \\
(-3.904)\end{array}$ & $\begin{array}{l}-0.674 \text { ** } \\
(-2.435)\end{array}$ & $\begin{array}{l}-0.733 \\
(-1.532)\end{array}$ & $\begin{array}{l}-0.582 * \\
(-1.973)\end{array}$ \\
\hline \multicolumn{2}{|c|}{ Error correction } & $\begin{array}{l}0.138^{*} \\
(1.831)\end{array}$ & $\begin{array}{c}-0.427^{* * *} \\
(-2.794)\end{array}$ & $\begin{array}{c}-0.416^{* * *} \\
(-4.190)\end{array}$ & $\begin{array}{c}-0.301 \text { ** } \\
(-2.13)\end{array}$ & $\begin{array}{l}-0.315^{* *} \\
(-2.143)\end{array}$ & $\begin{array}{c}-0.251^{* * *} \\
(-6.237)\end{array}$ & $\begin{array}{l}-0.379 \\
(-1.146) \\
\end{array}$ & $\begin{array}{l}-0.291 \text { ** } \\
(-2.101) \\
\end{array}$ & $\begin{array}{c}-0.313^{* * *} \\
(-3.850)\end{array}$ & $\begin{array}{l}-0.304^{* * *} \\
(-2.345) \\
\end{array}$ & $\begin{array}{c}-0.135^{* * *} \\
(-1.453)\end{array}$ & $\begin{array}{l}-0.421 \text { ***** } \\
(-2.890)\end{array}$ \\
\hline \multirow{4}{*}{$\begin{array}{l}\text { Short-run } \\
\text { coefficients }\end{array}$} & GDPPC & $\begin{array}{l}0.136^{*} \\
(1.841)\end{array}$ & $\begin{array}{c}-0.142 \\
(-1.219)\end{array}$ & $\begin{array}{l}-0.115^{*} \\
(-1.893)\end{array}$ & $\begin{array}{l}-1.750 \\
(-1.28)\end{array}$ & $\begin{array}{l}-0.019 \\
(-0.928)\end{array}$ & $\begin{array}{l}-0.225 \\
(-0.451)\end{array}$ & $\begin{array}{c}0.404 * * * * \\
(2.845)\end{array}$ & $\begin{array}{c}-0.897 \\
(-1.320)\end{array}$ & $\begin{array}{l}0.461 * * \\
(2.354)\end{array}$ & $\begin{array}{c}0.969 \\
(1.354)\end{array}$ & $\begin{array}{l}-0.437^{*} \\
(-1.355)\end{array}$ & $\begin{array}{l}0.234^{*} \\
(2.014)\end{array}$ \\
\hline & IS & $\begin{array}{l}0.480^{*} \\
(1.971)\end{array}$ & $\begin{array}{l}0.179 \text { ** } \\
(1.324)\end{array}$ & $\begin{array}{l}-0.261 \text { ** } \\
(-2.436)\end{array}$ & $\begin{array}{l}0.220 \text { ** } \\
(2.401)\end{array}$ & $\begin{array}{l}-0.251 * \\
(-1.840)\end{array}$ & $\begin{array}{c}0.391 \\
(0.202)\end{array}$ & $\begin{array}{l}-0.451 \text { ** } \\
(-2.142)\end{array}$ & $\begin{array}{c}0.029 \\
(0.640)\end{array}$ & $\begin{array}{l}-0.361 * \\
(-1.882)\end{array}$ & $\begin{array}{c}0.372 \\
(1.462)\end{array}$ & $\begin{array}{l}0.401 \text { ** } \\
(2.445)\end{array}$ & $\begin{array}{l}0.235^{* * *} \\
(2.133)\end{array}$ \\
\hline & FD & $\begin{array}{l}-0.312 * * \\
(-2.045)\end{array}$ & $\begin{array}{l}-0.364 * \\
(-1.813)\end{array}$ & $\begin{array}{l}-0.334 * * \\
(-2.201)\end{array}$ & $\begin{array}{l}0.254 * * * \\
(-5.605)\end{array}$ & $\begin{array}{c}0.829 \\
(1.340)\end{array}$ & $\begin{array}{c}0.913 \\
(0.251)\end{array}$ & $\begin{array}{l}0.542 * * * \\
(5.290)\end{array}$ & $\begin{array}{c}0.490 \\
(0.270)\end{array}$ & $\begin{array}{l}0.516^{* *} \\
(1.346)\end{array}$ & $\begin{array}{c}0.039 \\
(0.904)\end{array}$ & $\begin{array}{l}0.910 \\
(0.20)\end{array}$ & $\begin{array}{l}0.429 * \\
(1.821)\end{array}$ \\
\hline & $\mathrm{FD}^{2}$ & $\begin{array}{c}-0.231 * \\
(1.841)\end{array}$ & $\begin{array}{l}-0.532 * * \\
(2.289)\end{array}$ & $\begin{array}{l}-0.237 * * \\
(-2.184)\end{array}$ & $\begin{array}{l}-0.284 * \\
(-1.784)\end{array}$ & $\begin{array}{c}-0.841 \\
(-1.129)\end{array}$ & $\begin{array}{c}-0.418 \\
(-0.582)\end{array}$ & $\begin{array}{c}-0.031 \\
(-0.340)\end{array}$ & $\begin{array}{l}-0.158^{* *} \\
(-2.184)\end{array}$ & $\begin{array}{l}-0.917 * \\
(-1.942)\end{array}$ & $\begin{array}{l}-0.114 * \\
(-1.801)\end{array}$ & $\begin{array}{c}-0.994 \\
(-0.301)\end{array}$ & $\begin{array}{l}-0.151 * \\
(-1.794)\end{array}$ \\
\hline \multicolumn{2}{|c|}{ Constant } & $\begin{array}{c}-0.081 * * * \\
(-4.000)\end{array}$ & $\begin{array}{l}0.034 * * \\
(2.163)\end{array}$ & $\begin{array}{l}0.083 * * * \\
(3.901)\end{array}$ & $\begin{array}{c}0.072 * * * \\
(4.132)\end{array}$ & $\begin{array}{l}0.262 * * \\
(2.214)\end{array}$ & $\begin{array}{l}0.086^{* *} \\
(2.245)\end{array}$ & $\begin{array}{l}0.031 * * \\
(2.051)\end{array}$ & $\begin{array}{l}-0.048 * \\
(-1.910)\end{array}$ & $\begin{array}{c}0.071 * * * \\
(4.406)\end{array}$ & $\begin{array}{c}0.619 * * * \\
(3.410)\end{array}$ & $\begin{array}{l}0.381 * * \\
(2.400)\end{array}$ & $\begin{array}{l}0.212 * * * \\
(4.137)\end{array}$ \\
\hline \multicolumn{2}{|c|}{$\begin{array}{l}\text { Number of obs } \\
\text { Number of groups }\end{array}$} & & $\begin{array}{c}130 \\
10\end{array}$ & & & $\begin{array}{c}78 \\
6\end{array}$ & & & $\begin{array}{c}143 \\
11\end{array}$ & & & $\begin{array}{c}39 \\
3\end{array}$ & \\
\hline \multicolumn{2}{|c|}{ Hausman test } & $\begin{array}{l}1 \\
2 \\
3\end{array}$ & \multicolumn{2}{|c|}{ Prob $\geq 0.990$} & \multicolumn{3}{|c|}{$\begin{array}{l}\text { Prob }>0.991 \\
\text { Prob }>1.000\end{array}$} & \multicolumn{3}{|c|}{ Prob $\geq 0.993$} & \multicolumn{3}{|c|}{ Prob $\geq 0.998$} \\
\hline
\end{tabular}

Notes: (1) ${ }^{* * *}, * *$, and $*$ denote a significance of $1 \%, 5 \%$, and $10 \%$, respectively; (2) Hausman test 1, H0: The CPMG estimator is preferred than CMG estimator; (3) Hausman test 2, H0: The

CDFE estimator is preferred than CPMG estimator; (4) Hausman test 3, H0: The CDFE estimator is preferred than CMG estimator. 


\subsubsection{The Impact on Different Stages}

To increase more constructive suggestions on achieving the goal of carbon emissions reduction in China in 2020, this section studies the relationship between FD and CEPC in the 10th FYP, 11th FYP and 12th FYP. A detailed analysis of Table 7 is listed below:

(1) During the 10th FYP (2001-2005), stimulated by industrialization, urbanization and internationalization, the Chinese economy achieved rapid expansion, and the industrial structure tended toward high input, energy consumption and pollution. At that time, financial development promoted CEL, and each $1 \%$ increase of financial development caused a $0.816 \%$ increase in CEPC. Therefore, financial development aggravates the carbon emissions in this stage because of the outdated production capacity, increase of enterprises with high energy consumption, lagging production technology and low production efficiency [18].

(2) The 11th FYP was a transformative period for Chinese carbon emissions with remarkable progression of low-carbon development. The increase of carbon emissions was effectively alleviated, and the increasing tendency of CEL begins to decrease. Therefore, during this time, the economic development mode changes from an investment-led pattern to a science-led pattern. Financial development can promote CEL with a coefficient of 0.569. This confirms that although financial development can still increase carbon emissions, the impact effect greatly decreases. On the other hand, it shows that the strategies of energy conservation and emission reduction are effective and can contribute to low-carbon development.

(3) The 12th FYP is a key stage for China to develop its low-carbon economy. China further adjusted its energy structure, established an energy system, changed the industrial structure, promoted the development of low-carbon industries, and developed low-carbon technology. During this time, FD promoted CEL with a lower impact magnitude, which indicates that the low-carbon development mode accelerated the independent innovation process. The expansion of financing channels, continuous perfection of the carbon trade mechanism and improvement of technological research abilities are beneficial for China in realizing a low-carbon economy.

\subsubsection{The Impact of Different Aspects of Financial Development on CEL}

The empirical results in Table 8 show that the influence of seven specific aspects of financial development are not the same. Due to the limitation of the length of this paper, we only list the long-run results estimated by CDFE. From a national perspective, FSZ, FOP and FDP will increase carbon emissions, while FEF and FEC will help constrain the CEL. In each region, the influences are also different. Therefore, it is necessary to analyse each aspect and adjust the policies accordingly. The results are summarized in Table 9, and the influences of FST and FGR [98] are not statistically significant, so we will not discuss the two indicators. 
Table 7. Results of FD on CEL in different stages.

\begin{tabular}{|c|c|c|c|c|c|c|c|c|c|c|}
\hline & & \multicolumn{3}{|c|}{ 10th Five-Year Plan } & \multicolumn{3}{|c|}{ 11th Five-Year Plan } & \multicolumn{3}{|c|}{ 12th Five-Year Plan } \\
\hline & & CMG & CPMG & CDFE & CMG & CPMG & CDFE & CMG & CPMG & CDFE \\
\hline \multirow{4}{*}{$\begin{array}{l}\text { Long-run } \\
\text { coefficients }\end{array}$} & GDPPC & $\begin{array}{l}0.235^{*} \\
(1.941)\end{array}$ & $\begin{array}{l}0.248^{* *} \\
(2.193) \\
\end{array}$ & $\begin{array}{c}0.253 * * * \\
(4.972)\end{array}$ & $\begin{array}{c}0.258^{* *} \\
(2.349) \\
\end{array}$ & $\begin{array}{c}0.241^{* * *} \\
(4.153)\end{array}$ & $\begin{array}{c}0.292 * * * \\
(4.513)\end{array}$ & $\begin{array}{l}0.150 * * \\
(2.214)\end{array}$ & $\begin{array}{c}-0.112 * * * \\
(-2.839)\end{array}$ & $\begin{array}{c}-0.142 \text { *** } \\
(-3.514)\end{array}$ \\
\hline & IS & $\begin{array}{l}0.624^{* *} \\
(2.295)\end{array}$ & $\begin{array}{c}0.427^{* * *} \\
(4.512)\end{array}$ & $\begin{array}{l}0.720^{* *} \\
(1.986)\end{array}$ & $\begin{array}{c}0.449^{* * *} \\
(3.395)\end{array}$ & $\begin{array}{l}0.316^{*} \\
(1.912)\end{array}$ & $\begin{array}{l}0.552^{* *} \\
(2.215)\end{array}$ & $\begin{array}{l}0.241^{* *} \\
(2.127)\end{array}$ & $\begin{array}{c}0.051 \\
(0.990)\end{array}$ & $\begin{array}{l}0.301 \text { ** } \\
(2.198)\end{array}$ \\
\hline & FD & $\begin{array}{c}0.793 * * * \\
(4.417)\end{array}$ & $\begin{array}{l}0.774^{* *} \\
(2.249)\end{array}$ & $\begin{array}{c}0.816^{* * *} \\
(2.995)\end{array}$ & $\begin{array}{c}0.5132 \text { ** } \\
(2.310)\end{array}$ & $\begin{array}{c}0.414^{* * *} \\
(3.154)\end{array}$ & $\begin{array}{l}0.569^{* *} \\
(2.114)\end{array}$ & $\begin{array}{l}0.325^{* *} \\
(2.117)\end{array}$ & $\begin{array}{c}0.350 * * * \\
(5.214)\end{array}$ & $\begin{array}{c}0.257^{* * *} \\
(4.146)\end{array}$ \\
\hline & $\mathrm{FD}^{2}$ & $\begin{array}{l}-0.418^{* *} \\
(-2.251) \\
\end{array}$ & $\begin{array}{c}-0.162 \\
(-0.829) \\
\end{array}$ & $\begin{array}{l}-0.298 * * \\
(-2.263) \\
\end{array}$ & $\begin{array}{c}-0.172 \\
(-1.880) \\
\end{array}$ & $\begin{array}{c}-0.203 \\
(-0.619) \\
\end{array}$ & $\begin{array}{c}-0.283 \\
(-0.354) \\
\end{array}$ & $\begin{array}{c}0.682 \\
(0.292) \\
\end{array}$ & $\begin{array}{c}-0.541 \\
(-0.430) \\
\end{array}$ & $\begin{array}{c}0.823 \\
(0.514) \\
\end{array}$ \\
\hline \multicolumn{2}{|c|}{ Error correction } & $\begin{array}{l}-1.933 * * \\
(-1.923)\end{array}$ & $\begin{array}{l}-0.422 \text { ** } \\
(-2.125)\end{array}$ & $\begin{array}{c}-0.946^{* * *} \\
(-5.959)\end{array}$ & $\begin{array}{c}-0.354^{* * *} \\
(-3.719)\end{array}$ & $\begin{array}{l}-0.422 \text { ** } \\
(-2.124)\end{array}$ & $\begin{array}{c}-0.481 \text { *** } \\
(-3.081)\end{array}$ & $\begin{array}{l}-1.293^{* *} \\
(-1.904)\end{array}$ & $\begin{array}{c}-0.351 \\
(-0.980)\end{array}$ & $\begin{array}{c}-1.412 \text { *** } \\
(-5.523)\end{array}$ \\
\hline \multirow{4}{*}{$\begin{array}{l}\text { Short-run } \\
\text { coefficients }\end{array}$} & GDPPC & $\begin{array}{c}0.301 \\
(0.482)\end{array}$ & $\begin{array}{c}0.461 \\
(1.201) \\
\end{array}$ & $\begin{array}{c}-0.439^{* * *} \\
(-4.329)\end{array}$ & $\begin{array}{c}0.719 \\
(0.343) \\
\end{array}$ & $\begin{array}{l}0.193^{* *} \\
(2.273) \\
\end{array}$ & $\begin{array}{c}0.415 \\
(0.911) \\
\end{array}$ & $\begin{array}{l}-0.214 * \\
(-1.892)\end{array}$ & $\begin{array}{l}0.183^{* *} \\
(2.091) \\
\end{array}$ & $\begin{array}{l}-0.280 \text { ** } \\
(-2.142)\end{array}$ \\
\hline & IS & $\begin{array}{l}0.293^{*} \\
(1.982) \\
\end{array}$ & $\begin{array}{c}0.923 \\
(0.924) \\
\end{array}$ & $\begin{array}{l}0.142 * \\
(1.842) \\
\end{array}$ & $\begin{array}{c}0.993 \\
(0.030) \\
\end{array}$ & $\begin{array}{c}0.219^{* * *} \\
(2.906)\end{array}$ & $\begin{array}{c}2.327 \\
(0.092) \\
\end{array}$ & $\begin{array}{c}-0.011 \\
(-0.203) \\
\end{array}$ & $\begin{array}{c}-0.383 \\
(-0.330) \\
\end{array}$ & $\begin{array}{c}-0.282 \\
(-1.231) \\
\end{array}$ \\
\hline & FD & $\begin{array}{l}0.192 * \\
(1920)\end{array}$ & $\begin{array}{c}0.012 \\
(1.021)\end{array}$ & $\begin{array}{l}0.169 * \\
(1.981)\end{array}$ & $\begin{array}{c}-0.264 \\
(-0.239) \\
\end{array}$ & $\begin{array}{c}0.335 \\
(0.349) \\
\end{array}$ & $\begin{array}{l}-0.243^{* *} \\
(-2.211)\end{array}$ & $\begin{array}{c}-1.001 \\
(-0.032) \\
\end{array}$ & $\begin{array}{c}0.383 \\
(0.590)\end{array}$ & $\begin{array}{l}-0.342 * \\
(-1.953)\end{array}$ \\
\hline & $\mathrm{FD}^{2}$ & $\begin{array}{c}-0.213 \\
(-0.781)\end{array}$ & $\begin{array}{l}-0.258 * \\
(-1.811)\end{array}$ & $\begin{array}{l}-0.213^{*} \\
(-1.851)\end{array}$ & $\begin{array}{l}0.232 * \\
(1.914)\end{array}$ & $\begin{array}{c}-0.914 \\
(-1.228)\end{array}$ & $\begin{array}{c}0.839 \\
(1.019) \\
\end{array}$ & $\begin{array}{c}0.928 \\
(1.348) \\
\end{array}$ & $\begin{array}{c}-0.830 \\
(-0.921)\end{array}$ & $\begin{array}{c}0939 \\
(1.282) \\
\end{array}$ \\
\hline \multicolumn{2}{|c|}{ Constant } & $\begin{array}{l}0.021 * \\
(1.892)\end{array}$ & $\begin{array}{c}0.355 \\
(0.091) \\
\end{array}$ & $\begin{array}{l}-0.475 * \\
(-1.920)\end{array}$ & $\begin{array}{c}0.439 \\
(1.026) \\
\end{array}$ & $\begin{array}{l}-0.244^{* *} \\
(-2.248)\end{array}$ & $\begin{array}{l}0.214^{* *} \\
(2.044)\end{array}$ & $\begin{array}{c}0.312 \\
(0.720) \\
\end{array}$ & $\begin{array}{c}-1.883^{* * *} \\
(-4.028)\end{array}$ & $\begin{array}{l}1.251^{* *} \\
(2.122) \\
\end{array}$ \\
\hline \multicolumn{2}{|c|}{$\begin{array}{l}\text { Number of obs } \\
\text { Number of groups }\end{array}$} & \multicolumn{3}{|c|}{120} & \multicolumn{3}{|c|}{120} & \multicolumn{3}{|c|}{90} \\
\hline \multicolumn{2}{|c|}{ Hausman test } & & \multicolumn{2}{|r|}{$\begin{array}{l}\text { Prob } \geq 1.000 \\
\text { Prob } \geq 0.989 \\
\text { Prob } \geq 1.000\end{array}$} & \multicolumn{3}{|c|}{$\begin{array}{l}\text { Prob } \geq 1.000 \\
\text { Prob } \geq 0.993 \\
\text { Prob } \geq 1.000\end{array}$} & \multicolumn{3}{|c|}{$\begin{array}{l}\text { Prob } \geq 1.000 \\
\text { Prob } \geq 0.991 \\
\text { Prob } \geq 1.000\end{array}$} \\
\hline
\end{tabular}

Notes: $(1)^{* * * * * *}$, and ${ }^{*}$ denote a significance of $1 \%, 5 \%$, and $10 \%$, respectively; (2) Hausman test $1, \mathrm{H} 0$ : The CPMG estimator is preferr
The CDFE estimator is preferred than CPMG estimator; (4) Hausman test $3, \mathrm{H} 0$ : The CDFE estimator is preferred than CMG estimator. 
Table 8. Results of each aspect of financial development on CEL.

\begin{tabular}{|c|c|c|c|c|c|c|c|c|c|}
\hline Aspect & FSZ & FST & FOP & FDP & FGR & FEF & FEC & Error Correction & Constant \\
\hline Overall impact & $\begin{array}{c}0.369^{* * *} \\
(4.839)\end{array}$ & $\begin{array}{c}-0.246 \\
(-1.540)\end{array}$ & $\begin{array}{l}0.133^{* *} \\
(2.168)\end{array}$ & $\begin{array}{c}0.221^{* * *} \\
(4.901)\end{array}$ & $\begin{array}{c}-0.293 \\
(-1.409)\end{array}$ & $\begin{array}{l}-0.166^{* *} \\
(-2.213)\end{array}$ & $\begin{array}{l}-0.159 * \\
(-1.798)\end{array}$ & $\begin{array}{c}0.382^{* * *} \\
(3.829)\end{array}$ & $\begin{array}{c}-0.224^{* * *} \\
(-4.338)\end{array}$ \\
\hline Eastern region & $\begin{array}{c}-0.496^{* * *} \\
(-3.439)\end{array}$ & $\begin{array}{c}-0.410 \\
(-0.021)\end{array}$ & $\begin{array}{l}-0.284^{* *} \\
(-2.267)\end{array}$ & $\begin{array}{l}-0.142 \text { ** } \\
(-2.199)\end{array}$ & $\begin{array}{c}0.492 \\
(1.503)\end{array}$ & $\begin{array}{c}-0.398^{* * *} \\
(-4.839)\end{array}$ & $\begin{array}{l}-0.451^{* * *} \\
(-4.223)\end{array}$ & $\begin{array}{c}0.528^{* * *} \\
(5.490)\end{array}$ & $\begin{array}{c}-0.308^{* * *} \\
(-4.113)\end{array}$ \\
\hline Middle region & $\begin{array}{c}0.313^{* * *} \\
(2.904)\end{array}$ & $\begin{array}{c}0.351^{* * *} \\
(4.982)\end{array}$ & $\begin{array}{c}0.192^{* * *} \\
(3.904)\end{array}$ & $\begin{array}{c}0.129 * * * \\
(5.701)\end{array}$ & $\begin{array}{c}0.929 \\
(0.081)\end{array}$ & $\begin{array}{c}0.042 \\
(1.233)\end{array}$ & $\begin{array}{c}0.148^{* * *} \\
(2.312)\end{array}$ & $\begin{array}{c}0.551^{* * *} \\
(4.391)\end{array}$ & $\begin{array}{l}-0.218^{* *} \\
(-4.492)\end{array}$ \\
\hline Western region & $\begin{array}{l}0.235^{* *} \\
(2.152)\end{array}$ & $\begin{array}{c}-0.440 \\
(-0.092)\end{array}$ & $\begin{array}{c}0.926 \\
(1.450)\end{array}$ & $\begin{array}{c}0.105^{*} \\
(-1.915)\end{array}$ & $\begin{array}{l}-0.241 \text { ** } \\
(-2.135)\end{array}$ & $\begin{array}{c}0.282 \\
(0.010)\end{array}$ & $\begin{array}{l}-0.195^{* *} \\
(-1.982)\end{array}$ & $\begin{array}{c}0.345^{* * *} \\
(4.326)\end{array}$ & $\begin{array}{l}-0.209 \text { ** } \\
(-2.213)\end{array}$ \\
\hline Northeastern region & $\begin{array}{l}0.193^{* *} \\
(1.998)\end{array}$ & $\begin{array}{c}0.924 \\
(0.241)\end{array}$ & $\begin{array}{c}0.326^{* * * *} \\
(6.132)\end{array}$ & $\begin{array}{c}0.146 \\
(0.021)\end{array}$ & $\begin{array}{c}-2.410 \\
(-0.199)\end{array}$ & $\begin{array}{c}0.335^{* * *} \\
(4.213)\end{array}$ & $\begin{array}{c}-0.153 \\
(-1.288)\end{array}$ & $\begin{array}{c}0.590 \\
(1.095)\end{array}$ & $\begin{array}{c}-0.037^{* * *} \\
(-5.192)\end{array}$ \\
\hline
\end{tabular}


Table 9. Analysis of the impact of different aspects of financial development on carbon emissions.

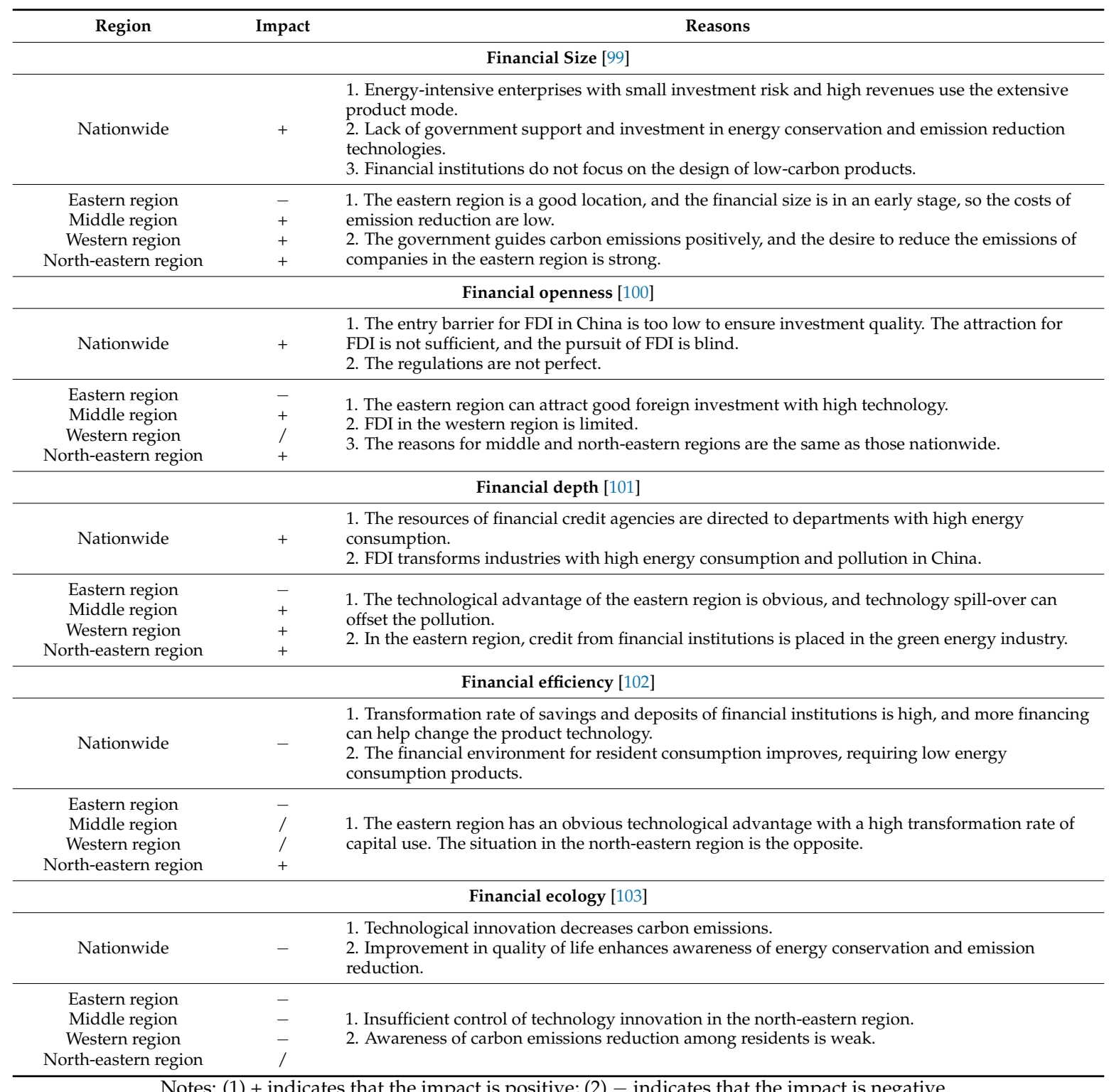

\section{Conclusions}

This paper aimed to study their relationship more deeply and thoroughly to theoretically and empirically contribute to carbon emissions reduction in China. The detailed conclusions are shown in Figure 5. Initially, a method for analysing carbon emissions considered 13 types of fossil fuels and cement, and a comprehensive index system to measure financial development is built based on the combination of a sequence global principal component analysis and the entropy weight method. Then, the extended STIARPAT model and dynamic error-correction model for panel data are employed to research the impact from the perspective of the entire country, regional differences and stage differences. Additionally, we also divide financial development into seven specific aspects to study their influences on carbon emissions. 


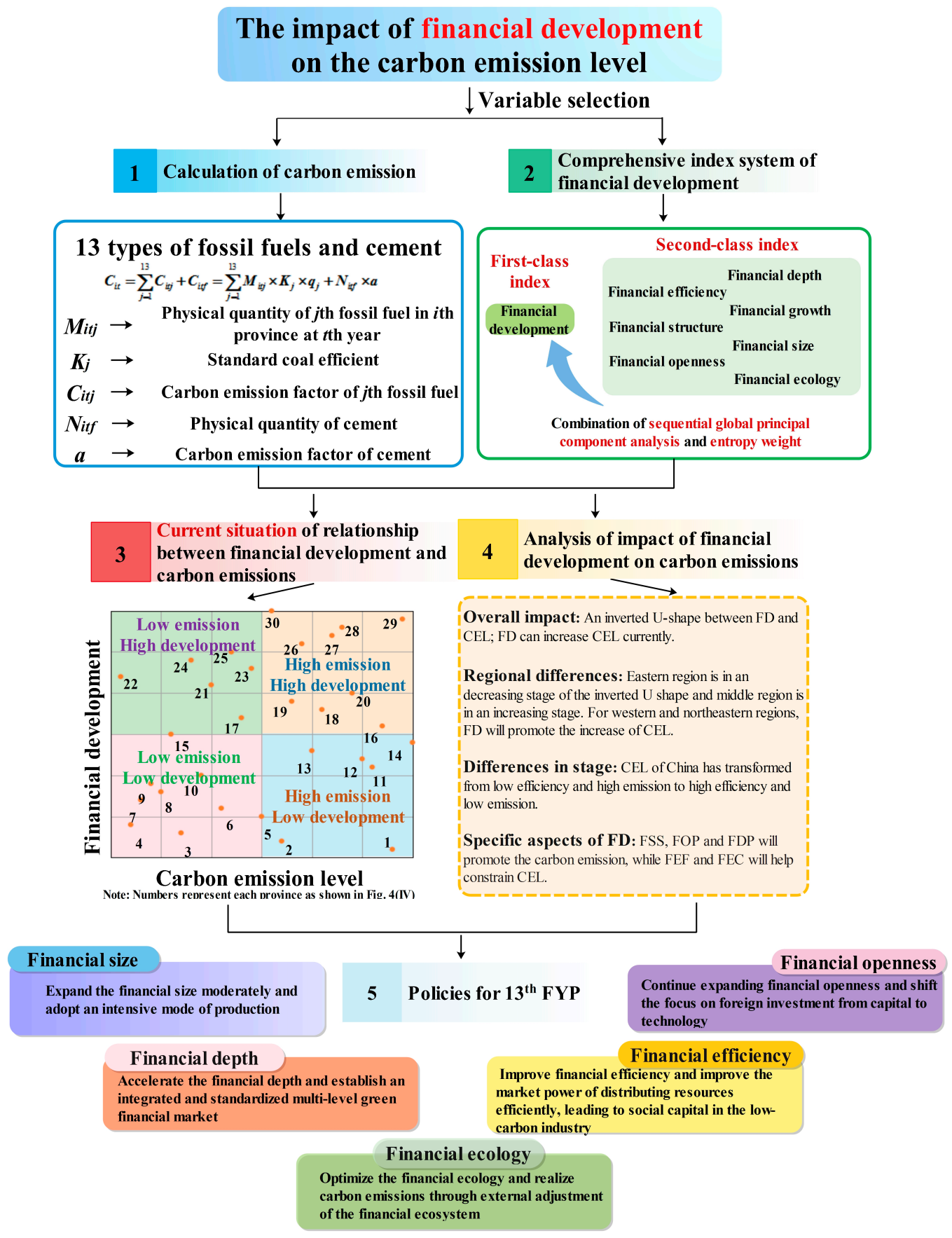

Figure 5. Summary of the research results.

The main research conclusions are summarized as follows: (1) From a national perspective, whether measuring CEL by using CEPC, there is an inverted U-shape between FD and CEL. Currently, the development of finance can increase carbon emissions greatly, which indicates that financial development plays a larger role in stimulating consumption and expanding the investment scale than in the technological advancement and structure updating; (2) The eastern region is in a decreasing stage in an inverted-U shape, and the middle region is in an increasing stage. For both western and north-eastern regions, the current financial development will promote the increase of carbon emissions; (3) During the 10th FYP, the increase of energy consumption leads to improvement of carbon emissions. The detrimental impact of financial development on CEL tends to be weaker during the 11th FYP because the economic growth mode begins to transform from an extensive to intensity mode. For the 
12th FYP, with the establishment of a resource-saving and environmentally friendly economic system, financial development will gradually constrain carbon emissions. In summary, carbon emissions in China have transformed from low efficiency and high emissions to high efficiency and low emissions; (4) Financial size, financial openness, and financial depth can facilitate the increase of carbon emissions; however, in comparison, financial efficiency and financial ecology can effectively constrain the carbon emissions level. The influences of financial structure and financial growth are not significant.

To sum up, we have proposed a novel approach and conducted a thorough and comprehensive study to analyse the impact of financial development on the carbon emissions level, which will be helpful for policy makers to develop corresponding policies to realize the goal of carbon emissions reduction and achieve sustainable development in China.

Based on the conclusions above, policies can be proposed for the 13th FYP in China to balance the relationship between financial development and the carbon emissions level. It can be seen that carbon emissions will be affected by financial development in terms of financial size, financial openness, financial depth, financial efficiency and financial ecology. Therefore, the Chinese government needs to propose reasonable and detailed suggestions and policies according to the abovementioned factors of financial development and focus on the gaps between developed regions and less developed regions by strengthening technological cooperation and adjusting the measures to local conditions. The detailed policies on controlling carbon emissions are listed below:

- Expand the financial size moderately and adopt an intensive mode of production

Increasing financial size will lead to the increase of carbon emissions; however, this does not mean that the expansion of financial size prevents carbon emissions reduction. In contrast, expanding the financial size reasonably can increase the fund supply, which can help reduce the costs of introducing low-carbon technologies and increasing the motivation of enterprises to reduce carbon emissions. Therefore, the idea is to adjust the production mode of enterprises from an extensive pattern to an intensive pattern and eliminate companies with high emissions and overcapacity. The government should intensify supervision and implement regulations and rules promoting low-carbon development to avoid uncontrolled expansion of the financial size.

- Continue expanding financial openness and shift the focus on foreign investment from capital to technology

Expanding financial openness is beneficial, but the low entrance threshold and weak national competitiveness will result in low FDI investment quality, which can further increase unnecessary carbon emissions. Therefore, while expanding financial openness, the barriers to entry for the market should be improved. Additionally, developing countries also need to increase the appeal to FDI by reinforcing competitiveness, and the focus of foreign investment should be on the technology level instead of the capital scale. Finally, the government should guide foreign investment in the low-carbon industry and encourage financial creation, such as carbon finance, carbon bonds and so on.

- Accelerate the financial depth and establish an integrated and standardized multi-level green financial market

First, extending bank reform and the financial industry is beneficial to attracting investment in environmental protection facilities and technology, are necessary. Second, financial institutions should increase green-credit loans and encourage more investment in the environmental protection industry. Low-carbon enterprises can realize indirect financial gains through green credit and intermediary services of carbon finance. The government also needs to increase its support of the low-carbon industry and expand the direct financing of low-carbon enterprises by building green channels for their listing and establishing a carbon exchange market to guide capital to the low-carbon industry.

- Improve financial efficiency and improve the market power of distributing resources efficiently, leading to social capital in the low-carbon industry 
On the one hand, both the conversion rate of deposit and the loan and utilization efficiency of financial capital should be improved. Financial institutions should track the management of enterprise capital, and more capital should be used to change the production technology of enterprises. On the other hand, the low-carbon consumption of residents should be improved so they purchase more low-energy consuming to optimize the financial environment of consumption.

- Optimize the financial ecology and realize carbon emissions through external adjustment of the financial ecosystem

First, the government should actively improve the financial ecological environment instead of passively meeting the requirements of economic activity. Accelerating improvement of financial ecology is beneficial for promoting energy conservation and emissions reduction of the real economy and achieving a low-carbon pattern earlier. Second, a certification system for low-carbon products should be created to increase awareness of low-carbon consumption by residents. Financial institutions can provide detailed channels to reduce carbon emissions by developing new carbon-related products. Finally, the government should encourage financial institutions to perform financial innovation of low-carbon products to offer companies and individual customers more opportunities to invest in the low-carbon industry, supporting carbon emissions reduction and low-carbon economic development.

Author Contributions: Tiancai Xing proposed the idea of this paper and made overall guidance; Qichuan Jiang completed the whole paper; Xuejiao Ma made figures and tables and helped rechecked the paper.

Conflicts of Interest: The authors declare no conflict of interest.

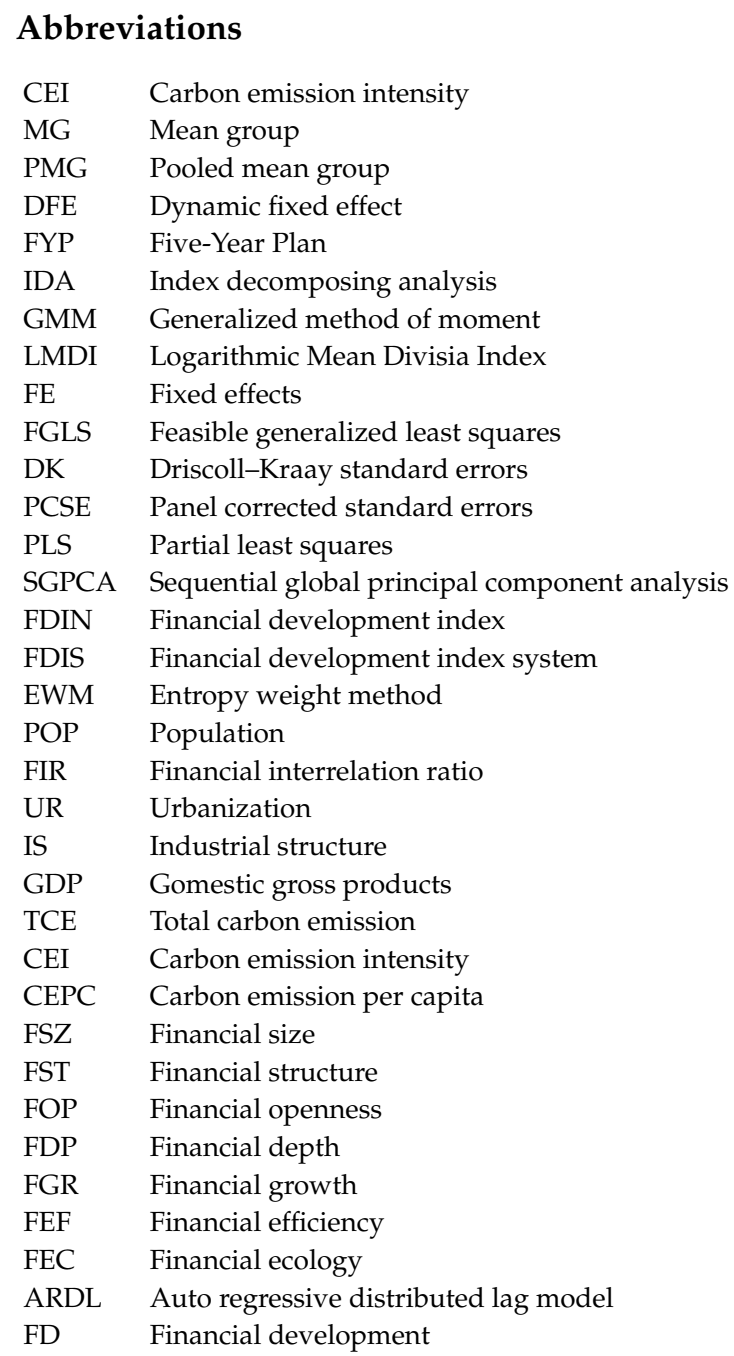


CEL Carbon emission level

IPCC Intergovernmental Panel on Climate Change

KMO Kaiser-Meyer-Olkin

HE-HD High emission-high development

HE-LD High emission-low development

LE-HD Low emission-high development

LE-LD Low emission-low development

CD Cross-sectional dependence 


\section{Appendix A}

Table A1. Contributions and policies of China related to the emissions reduction.

\begin{tabular}{|c|c|c|}
\hline Time & Name of Policy & Related Contents \\
\hline January 2017 & $\begin{array}{l}\text { The Comprehensive Working Plan for Energy Conservation } \\
\text { and Emission Reduction during the 13th Five Year Plan }\end{array}$ & $\begin{array}{l}\text { Assign total energy consumption and intensity goals for each province (city and } \\
\text { district), propose goals for primary industries and clarify the control plan for } \mathrm{CO}_{2} \\
\text { total discharge levels in each region. }\end{array}$ \\
\hline June 2016 & Regulations of Industrial Energy Conservation & $\begin{array}{l}\text { Emphasize a transaction system of energy use rights, clarify the management } \\
\text { methods for energy saving and build a healthy and sound supervision system. }\end{array}$ \\
\hline September 2014 & $\begin{array}{l}\text { Action Plan for Transformation and Updating of Energy } \\
\text { Conservation and Emission Reduction of Coal (2014-2020) }\end{array}$ & $\begin{array}{l}\text { Until 2020, the average coal consumption power supply of newly built coal-fired } \\
\text { generating units should be lower than } 300 \mathrm{~g} / \mathrm{kWh} \text {. Transformational active units } \\
\text { should be lower than } 310 \mathrm{~g} / \mathrm{kWh} \text {. }\end{array}$ \\
\hline April 2014 & Revise Environmental Protection Act & $\begin{array}{l}\text { Highlight the cyclical utilization of resources and environmental improvement and } \\
\text { protection to coordinate social and economic development and } \\
\text { environmental protection. }\end{array}$ \\
\hline September 2013 & Action Plan for the Control of Air Pollution & Increase the selected ratio of raw coal to $70 \%$. \\
\hline July 2012 & Revise Cleaner Production Promotion Law & $\begin{array}{l}\text { Promote cleaner production, improve the utilization efficiency of resources, reduce } \\
\text { and prevent pollution, and protect the environment. }\end{array}$ \\
\hline August 2011 & $\begin{array}{l}\text { Comprehensive Working Plan for Energy Conservation and } \\
\text { Emissions Reduction during the 12th Five Year Plan }\end{array}$ & $\begin{array}{l}\text { Aim to decrease carbon emissions intensity by } 17 \% \text { in } 2015 \text { compared to } 2010 \text { within } \\
\text { the national economy and social development plan of the 12th Five Year Plan. }\end{array}$ \\
\hline April 2010 & Revise Renewable Energy Law & $\begin{array}{l}\text { Enhance the development and utilization of renewable energy and promote the } \\
\text { rapid and orderly development of renewable energy industries. }\end{array}$ \\
\hline April 2008 & Energy Conservation Law & $\begin{array}{l}\text { Promote energy conservation, improve the utilization efficiency of energy and } \\
\text { promote comprehensive, harmonious and sustainable development. }\end{array}$ \\
\hline March 2006 & The 11th Five Year Plan & Aim to decrease energy consumption by $20 \%$ \\
\hline August 2002 & Kyoto Protocol & Aim to decrease carbon emissions by $40-45 \%$ by 2020 compared to 2005 . \\
\hline
\end{tabular}




\section{Appendix B}

Table A2. Integrated weight of each indicator.

\begin{tabular}{cccccccccccc}
\hline Component & $\mathrm{X} 1$ & $\mathrm{X} 2$ & $\mathrm{X} 3$ & $\mathrm{X} 4$ & $\mathrm{X} 5$ & $\mathrm{X} 6$ & $\mathrm{X} 7$ & $\mathrm{X} 8$ & $\mathrm{X} 9$ & $\mathrm{X} 10$ & $\mathrm{X} 11$ \\
\hline $\begin{array}{c}\text { Principal } \\
\text { component method }\end{array}$ & 0.0411 & 0.0330 & 0.0383 & 0.0362 & 0.0503 & 0.033 & 0.0682 & 0.072 & 0.0285 & 0.0355 & 0.0221 \\
\hline $\begin{array}{c}\text { Entropy weight } \\
\text { method } \\
\text { Average }\end{array}$ & 0.0398 & 0.0243 & 0.0456 & 0.0458 & 0.0494 & 0.0366 & 0.0485 & 0.0486 & 0.0398 & 0.0545 & 0.0486 \\
\hline Component & $\mathrm{X}_{12}$ & $\mathrm{X}_{13}$ & $\mathrm{X}_{14}$ & $\mathrm{X}_{15}$ & $\mathrm{X}_{16}$ & $\mathrm{X}_{17}$ & $\mathrm{X}_{18}$ & $\mathrm{X}_{19}$ & $\mathrm{X}_{20}$ & $\mathrm{X}_{21}$ & $\mathrm{X}_{22}$ \\
\hline $\begin{array}{c}\text { Principal } \\
\text { component method }\end{array}$ & 0.0175 & 0.0321 & 0.0369 & 0.0691 & 0.0696 & 0.0653 & 0.0646 & 0.0245 & 0.0668 & 0.0268 & 0.0684 \\
\hline $\begin{array}{c}\text { Entropy weight } \\
\text { method } \\
\text { Average }\end{array}$ & 0.0444 & 0.0481 & 0.0470 & 0.0401 & 0.0485 & 0.0483 & 0.0493 & 0.0483 & 0.0497 & 0.0492 & 0.0457 \\
\hline
\end{tabular}

\section{Appendix C. Cross-Sectional Dependence (CD), Panel Unit Root Test and Panel Cointegration Tests}

Before discussing the empirical results of the relationship between financial development and carbon emissions, we need to solve three issues during the modelling process. One of the issues to be addressed is to test whether there is a cross-sectional dependence. Considering that the problem of inaccurate estimates of models can result from variable or residual correction across panel members owing to the spill-over effect and global common shocks, the cross-sectional dependence test is performed by applying the method developed by Pesaran [104]. The null hypothesis is that there is no cross-sectional dependence; accordingly, the alternative hypothesis is that cross-sectional dependence exists. The CD test is robust to the presence of multi-breaks in slope coefficients and in error variance. The results in Table A3 clearly show that the null hypothesis of no cross-sectional dependence is rejected in all models ( $p$-value is 0.000 ).

Table A3. Cross-sectional dependence test.

\begin{tabular}{cccccccc}
\hline Variable & CD-Test & $\boldsymbol{p}$-Value & Abs(corr) & Variable & CD-Test & $\boldsymbol{p}$-Value & Abs(corr) \\
\hline CEPC & 63.520 & 0.000 & 0.890 & FST & 52.350 & 0.000 & 0.775 \\
GDPPC & 75.430 & 0.000 & 0.976 & FOP & 53.880 & 0.000 & 0.719 \\
IS & 32.630 & 0.000 & 0.628 & FDP & 37.660 & 0.000 & 0.533 \\
FD & 53.970 & 0.000 & 0.692 & FGR & 48.700 & 0.000 & 0.626 \\
FD $^{2}$ & 48.400 & 0.000 & 0.627 & FEF & 38.170 & 0.000 & 0.515 \\
FSZ & 75.040 & 0.000 & 0.962 & FEC & 22.210 & 0.000 & 0.361 \\
\hline
\end{tabular}

The second issue that needs to be addressed is to test for the presence of unit roots in panel data. Kim et al. [105] demonstrated that the PMG estimation of an ARDL regression could provide consistent estimators if there were a unique cointegration vector that defined the long-term relationship among variables regardless of the $I(0)$ or $I(1)$ process. Basically, this method does not require pre-unit root testing of the variables. PMG cannot be applicable to I(2) or a higher series. Consequently, we test the presence of a unit root by adopting the CIPS test proposed by Pesaran [106]. The null hypothesis of the test is that there is a unit root (non-stationarity) in the original time series; if the null is rejected in levels, the series is an $I(0)$ process; if the null is not rejected in levels but is rejected in the first differences, the series is an I(1) process. The results in Table A4 indicate that the original level of the variables does not reject the null hypothesis that their series contain unit roots. However, the results for the estimation of the first difference of variables strongly reject the null hypothesis. Thus, the test proves that the series of all variables are $I(1)$ processes. As a result, the variables need to be cointegrated into the model [107]. 
Table A4. Results of panel unit roots tests.

\begin{tabular}{cccccccccccccc}
\hline \multicolumn{1}{c}{ Variables in Levels } \\
\hline \multicolumn{1}{c}{ Constant w/o Trend } & \multicolumn{3}{c}{ Constant w/Trend } & \multicolumn{4}{c}{ Constant w/o Trend } & \multicolumn{3}{c}{ Constant w/Trend } \\
\hline No. lag & $\mathbf{1}$ & $\mathbf{2}$ & $\mathbf{3}$ & $\mathbf{1}$ & $\mathbf{2}$ & $\mathbf{3}$ & $\mathbf{1}$ & $\mathbf{2}$ & $\mathbf{3}$ & $\mathbf{1}$ & $\mathbf{2}$ & $\mathbf{3}$ \\
\hline CEPC & 0.796 & 0.883 & 0.891 & 0.996 & 0.994 & 0.998 & 0.000 & 0.000 & 0.000 & 0.000 & 0.000 & 0.000 \\
GDPPC & 0.574 & 0.629 & 0.735 & 0.965 & 0.978 & 0.993 & 0.000 & 0.000 & 0.000 & 0.000 & 0.000 & 0.000 \\
IS & 0.072 & 0.139 & 0.168 & 0.471 & 0.669 & 0.705 & 0.000 & 0.000 & 0.000 & 0.000 & 0.000 & 0.000 \\
FD & 0.905 & 0.945 & 0.911 & 0.920 & 0.946 & 0.998 & 0.000 & 0.000 & 0.000 & 0.000 & 0.000 & 0.000 \\
FD & 0.918 & 0.936 & 0.900 & 0.972 & 0.963 & 0.977 & 0.000 & 0.000 & 0.000 & 0.000 & 0.000 & 0.000 \\
FSZ & 0.624 & 0.958 & 0.972 & 0.982 & 0.987 & 1.000 & 0.000 & 0.000 & 0.000 & 0.000 & 0.000 & 0.000 \\
FST & 0.946 & 0.998 & 0.999 & 0.703 & 0.996 & 0.999 & 0.000 & 0.000 & 0.000 & 0.000 & 0.000 & 0.000 \\
FOP & 0.874 & 0.889 & 0.903 & 0.641 & 0.993 & 0.817 & 0.000 & 0.000 & 0.000 & 0.000 & 0.000 & 0.000 \\
FDP & 0.318 & 0.856 & 0.774 & 0.621 & 1.000 & 0.999 & 0.000 & 0.000 & 0.000 & 0.000 & 0.000 & 0.000 \\
FGR & 0.568 & 0.626 & 0.888 & 0.825 & 0.945 & 0.991 & 0.000 & 0.000 & 0.000 & 0.000 & 0.000 & 0.000 \\
FEF & 0.838 & 0.851 & 0.998 & 0.617 & 1.000 & 0.995 & 0.000 & 0.000 & 0.000 & 0.000 & 0.000 & 0.000 \\
FEC & 0.302 & 0.492 & 0.517 & 0.806 & 0.885 & 0.793 & 0.000 & 0.000 & 0.000 & 0.000 & 0.000 & 0.000 \\
\hline
\end{tabular}

Since most variables are non-stationary, the third issue to be solved is to test for panel cointegration, and the test results are shown in Table A5. The error correction-based cointegration tests developed by Westerlund [108] are used to test the null hypothesis of no cointegration between the carbon emissions and each explanatory variable. The first group of statistics, Gt and Gs, has a null hypothesis of no cointegration, and the alternative hypothesis is that there is at least one group of cointegration relationships. The second group of statistics, $\mathrm{Pt}$ and $\mathrm{Ps}$, has the same null hypothesis as the first group, and the alternative hypothesis is that there is a cointegration relationship in the whole panel of data. From Table A5, it can be seen that most of the statistics of the error correction-based cointegration tests are significant, rejecting the null hypothesis at the $10 \%$ level or better.

Table A5. Results of panel cointegration tests.

\begin{tabular}{cccccccccccc}
\hline CEPC & GDPPC & IS & FD & FD $^{2}$ & FSZ & FST & FOP & FDP & FGR & FEF & FEC \\
\hline \multirow{2}{*}{ Gt } & 0.428 & 1.955 & 6.242 & 3.471 & 0.601 & 2.309 & 0.631 & 5.404 & 6.140 & 5.883 & 1.208 \\
& $(0.006)$ & $(0.975)$ & $(1.000)$ & $(1.000)$ & $(0.026)$ & $(0.000)$ & $(0.736)$ & $(0.000)$ & $(1.000)$ & $(0.000)$ & $(0.006)$ \\
\hline \multirow{2}{*}{$\mathrm{Ga}$} & -3.716 & -5.510 & -2.657 & -6.692 & -5.091 & -5.468 & -5.667 & -3.399 & -2.307 & -3.681 & -5.379 \\
& $(0.000)$ & $(0.000)$ & $(0.004)$ & $(0.000)$ & $(0.000)$ & $(0.000)$ & $(0.000)$ & $(0.000)$ & $(0.011)$ & $(0.000)$ & $(0.000)$ \\
\hline \multirow{2}{*}{$\mathrm{Pt}$} & 0.815 & -0.009 & 4.420 & 1.874 & -0.776 & -1.734 & -2.589 & 1.628 & 4.616 & 3.517 & 0.676 \\
& $(0.001)$ & $(0.096)$ & $(1.000)$ & $(0.070)$ & $(0.219)$ & $(0.042)$ & $(0.005)$ & $(0.048)$ & $(0.000)$ & $(0.000)$ & $(0.050)$ \\
\hline \multirow{2}{*}{$\mathrm{Pa}$} & -3.969 & -5.407 & -0.357 & -3.214 & -4.499 & -7.197 & -6.945 & -2.991 & -0.256 & -2.805 & -4.555 \\
& $(0.000)$ & $(0.000)$ & $(0.010)$ & $(0.001)$ & $(0.000)$ & $(0.000)$ & $(0.000)$ & $(0.001)$ & $(0.009)$ & $(0.003)$ & $(0.000)$ \\
\hline
\end{tabular}

\section{Appendix D. Regional Division of China}

Table A6. Regions division of China.

\begin{tabular}{cl}
\hline Region & \multicolumn{1}{c}{ Provinces } \\
\hline Eastern & Beijing, Tianjin, Hebei, Shanghai, Jiangsu, Zhejiang, Fujian, Shandong, Guangdong and Hainan. \\
\hline Middle & Shanxi, Anhui, Jiangxi, Henan, Hubei and Hunan. \\
\hline \multirow{2}{*}{ Western } & $\begin{array}{l}\text { Inner Mongolia, Guangxi, Chongqing, Sichuan, Guizhou, Yunnan, Xizang, Shaanxi, Gansu, Qinghai, } \\
\text { Ningxia and Xinjiang. }\end{array}$ \\
\hline Northeastern & Liaoning, Jilin and Heilongjiang. \\
\hline
\end{tabular}




\section{References}

1. Shahbaz, M.; Tiwari, A.K.; Nasir, M. The effects of financial development, economic growth, coal consumption and trade openness on $\mathrm{CO}_{2}$ emissions in South Africa. Energy Policy 2013, 61, 1452-1459. [CrossRef]

2. Charfeddine, L.; Khediri, K.B. Financial development and environmental quality in UAE: Cointegration with structural breaks. Renew. Sustain. Energy Rev. 2016, 55, 1322-1335. [CrossRef]

3. Zeng, S.; Liu, Y.; Liu, C.; Nan, X. A review of renewable energy investment in the BRICS countries: History, models, problems and solutions. Renew. Sustain. Energy Rev. 2017, 74, 860-872. [CrossRef]

4. Wang, Y.; Yang, X.; Sun, M.; Ma, L.; Li, X.; Shi, L. Estimating carbon emissions from the pulp and paper industry: A case study. Appl. Energy 2016, 184, 779-789. [CrossRef]

5. Carbon Trade, Global Carbon Project Issues the Carbon Emission Amount. Available online: http://www. tanjiaoyi.com/article-3258--1.html (accessed on 5 April 2016).

6. CDIAC, Carbon Emission of Top 20 Countries in the World in 2013. Available online: http:/ / cdiac.ornl.gov / trends/emis/top2013.tot (accessed on 5 April 2016).

7. Meng, F.; Su, B.; Thomson, E.; Zhou, D.; Zhou, P. Measuring China's regional energy and carbon emission efficiency with DEA models: A survey. Appl. Energy 2016, 183, 1-21. [CrossRef]

8. Zeng, S.; Nan, X.; Liu, C.; Chen, J. The response of the Beijing carbon emissions allowance price (BJC) to macroeconomic and energy price indices. Energy Policy 2017, 106, 111-121. [CrossRef]

9. CDIAC, Carbon Emission of China from 1978 to 2013. Available online: http://cdiac.ornl.gov/CO2_ Emission/timeseries/national/China (accessed on 5 April 2016).

10. Kim, J.; Park, K. Financial development and deployment of renewable energy technologies. Energy Econ. 2016, 59, 238-250. [CrossRef]

11. Ziaei, S.M. Effects of financial development indicators on energy consumption and $\mathrm{CO}_{2}$ emission of European, East Asian and Oceania countries. Renew. Sustain. Energy Rev. 2015, 42, 752-759. [CrossRef]

12. Xiong, L.; Qi, S.Z. Financial development and carbon emission of Chinese provinces: Based on STIRPAT model and dynamic panel data analysis. J. China Univ. Geosci. (Soc. Sci. Ed.) 2016, 16, 63-73. (In Chinese)

13. Wang, Y.F.; Zhao, H.Y.; Li, L.Y.; Liu, Z.; Liang, S. Carbon dioxide emission drivers for a typical metropolis using input-output structural decomposition analysis. Energy Policy 2013, 58, 312-318. [CrossRef]

14. Karmellos, M.; Kopidou, D.; Diakoulaki, D. A decomposition analysis of the driving factors of $\mathrm{CO}_{2}$ (carbon dioxide) emissions from the power sector in the European Union countries. Energy 2016, 94, 680-692. [CrossRef]

15. Shahiduzzaman, M.; Layton, A. Decomposition analysis for assessing the United States 2025 emissions target: How big is the challenge? Renew. Sustain. Energy Rev. 2017, 67, 372-383. [CrossRef]

16. Yan, Q.Y.; Zhang, Q.; Zou, X. Decomposition analysis of carbon dioxide emissions in China's regional thermal electricity generation, 2000-2020. Energy 2016, 112, 788-794. [CrossRef]

17. Li, A.J.; Zhang, A.Z.; Zhou, Y.X.; Yao, X. Decomposition analysis of factors affecting carbon dioxide emissions across provinces in China. J. Clean. Prod. 2017, 141, 1428-1444. [CrossRef]

18. Zhou, Y.; Liu, Y.S.; Wu, W.X.; Li, Y.R. Effects of rural-urban development transformation on energy consumption and $\mathrm{CO}_{2}$ emissions: A regional analysis in China. Renew. Sustain. Energy Rev. 2015, 52, 863-875. [CrossRef]

19. Zhang, C.G.; Zhou, X.X. Does foreign direct investment lead to lower $\mathrm{CO}_{2}$ emissions? Evidence from a regional analysis in China. Renew. Sustain. Energy Rev. 2016, 58, 943-951. [CrossRef]

20. Wang, P.; Wu, W.S.; Zhu, B.Z.; Wei, Y.M. Examining the impact factors of energy-related $\mathrm{CO}_{2}$ emissions using STIRPAT model in Guangdong province, China. Appl. Energy 2013, 106, 65-71. [CrossRef]

21. Li, H.N.; Mu, H.L.; Zhang, M.; Li, N. Analysis on influence factors of China's $\mathrm{CO}_{2}$ emissions based on Path-STIRPAT model. Energy Policy 2011, 39, 6906-6911. [CrossRef]

22. Wang, C.J.; Wang, F.; Zhang, X.L.; Yang, Y.; Su, Y.X.; Ye, Y.Y.; Zhang, H.G. Examining the driving factors of energy related carbon emissions using the extended STIRPAT model based on IPAT identity in Xinjiang. Renew. Sustain. Energy Rev. 2017, 67, 51-61. [CrossRef]

23. Danish; Zhang, B.; Wang, B.; Wang, Z.H. Role of renewable energy and non-renewable energy consumption on EKC: Evidence from Pakistan. J. Clean. Prod. 2017, 156, 855-864. 
24. Park, S.; Lee, Y. Regional model of EKC for air pollution: Evidence from the Republic of Korea. Energy Policy 2011, 39, 5840-5849. [CrossRef]

25. Haq, I.; Zhu, S.J.; Shafiq, M. Empirical investigation of environmental Kuznets curve for carbon emission in Morocco. Ecol. Indic. 2016, 67, 491-496. [CrossRef]

26. Wang, Y.; Zhang, C.; Lu, A.T.; Li, L.; He, Y.M.; Tojo, J.; Zhu, X.D. A disaggregated analysis of the environmental Kuznets curve for industrial $\mathrm{CO}_{2}$ emissions in China. Appl. Energy 2017, 190, 172-180. [CrossRef]

27. Ahmad, N.; Du, L.S.; Lu, J.Y.; Wang, J.L.; Li, H.Z.; Hashmi, M.Z. Modelling the $\mathrm{CO}_{2}$ emissions and economic growth in Croatia: Is there any environmental Kuznets curve? Energy 2017, 123, 164-172. [CrossRef]

28. Shuai, C.Y.; Chen, X.; Shen, L.Y.; Jiao, L.D.; Wu, Y.; Tan, Y.T. The urbing points of carbon Kuznets curve: Evidences from panel and time-series data of 164 countries. J. Clean. Prod. 2017, 162, 1031-1047. [CrossRef]

29. Liddle, B. What are the carbon emissions elasticities for income and population? Bridging STIRPAT and EKC via robust heterogeneous panel estimates. Glob. Environ. Chang. 2015, 31, 62-73. [CrossRef]

30. Liddle, B. Population, affluence, and environmental impact across development: Evidence from panel cointegration modeling. Environ. Model. Softw. 2013, 40, 255-266. [CrossRef]

31. Itkonen, J. Problems estimating the carbon Kuznets curve. Energy 2012, 39, 274-280. [CrossRef]

32. Beak, J.; Kim, H.S. Is economic growth good or bad for the environment? Empirical evidence from Korea. Energy Econ. 2013, 36, 744-749. [CrossRef]

33. Saboori, B.; Sulaiman, J. $\mathrm{CO}_{2}$ emissions, energy consumption and economic growth in Association of Southeast Asian Nations (ASEAN) countries: A cointegration approach. Energy 2013, 55, 813-822. [CrossRef]

34. Ndoricimpa, A. Analysis of asymmetries in the nexus among energy use, pollution emissions and real output in South Africa. Energy 2017, 125, 543-551. [CrossRef]

35. Goldsmith, R. Financial Structure and Development; Yale University Press: New Haven, CT, USA, 1969.

36. McKinnon, R. Money and Capital in Economic Development; Brooking Institution: Washington, DC, USA, 1973.

37. King, R.; Levine, R. Finance and growth: Schumpeter might be right. Quart. J. Econ. 1993, 108, 717-737. [CrossRef]

38. Levine, R.; Zeroes, S. Stock markets, banks and growth. Am. Rev. 1998, 88, 537-558.

39. Khan, M.S.; Senhadji, A. Financial development and economic growth: An overview. IMF Work. Pap. 2000, 209, 413-433. [CrossRef]

40. Beck, T.; Levine, R. Stock markets, banks and growth: Panel evidence. SSRN Electr. J. 2002, 28, $423-442$.

41. Acharyya, J. FDI, growth and the environment: Evidence from India on $\mathrm{CO}_{2}$ emission during the last two decades. J. Econ. Dev. 2009, 34, 43-58.

42. Coondoo, D.; Dinda, S. Causality between income and emission: A country-group specific econometric analysis. Ecol. Econ. 2002, 40, 351-367. [CrossRef]

43. Chakraborty, D.; Mukherjee, S. How do trade and investment flows affect environmental sustainability? Evidence from panel data. Environ. Dev. 2013, 6, 34-47. [CrossRef]

44. Acaravci, A.; Ozturk, I. On the relationship between energy consumption, $\mathrm{CO}_{2}$ emissions and economic growth in Europe. Energy 2010, 35, 5412-5420. [CrossRef]

45. Shahbaz, M.; Hye, Q.M.A.; Tiwari, A.K.; Leitão, N.C. Economic growth, energy consumption, financial development, international trade and $\mathrm{CO}_{2}$ emissions in Indonesia. Renew. Sustain. Energy Rev. 2013, 25, 109-121. [CrossRef]

46. Bekhet, H.A.; Matar, A.; Yasmin, T. $\mathrm{CO}_{2}$ emissions, energy consumption, economic growth and financial development in GCC countries: Dynamic simultaneous equation models. Renew. Sustain. Energy Rev. 2017, 70, 117-132. [CrossRef]

47. Katircioglu, S.T.; Taspinar, N. Testing the moderating role of financial development in an environmental Kuznets curve: Empirical evidence from Turkey. Renew. Sustain. Energy Rev. 2017, 68, 572-586. [CrossRef]

48. Shahzad, S.; Kumar, R.; Zakaria, M.; Hurr, M. Carbon emission, energy consumption, trade openness and financial development in Pakistan: A revisit. Renew. Sustain. Energy Rev. 2017, 70, 185-192. [CrossRef]

49. Cole, M.A.; Elliott, R.J.R.; Fredriksson, P.G. Endogenous pollution havens: Does FDI influence environmental regulations? Scand. J. Econ. 2006, 108, 157-178. [CrossRef]

50. He, J. Pollution haven hypothesis and environmental impacts of foreign direct investment: The case of industrial emission of sulfur dioxide $\left(\mathrm{SO}_{2}\right)$ in Chinese provinces. Ecol. Econ. 2006, 60, 228-245. [CrossRef] 
51. Ibrahim, M.H.; Law, S.H. Social capital and $\mathrm{CO}_{2}$ emission-Output relations: A panel analysis. Renew. Sustain. Energy Rev. 2014, 29, 528-534. [CrossRef]

52. Halkos, G.E.; Paizanos, E.A. The effect of government expenditure on the environment: An empirical investigation. Ecol. Econ. 2013, 91, 48-56. [CrossRef]

53. Pesaran, M.H. A simple panel unit root test in the presence of cross-section dependence. J. Appl. Econ. 2007, 22, 265-312. [CrossRef]

54. Adewuyi, A.O. Effects of public and private expenditures on environmental pollution: A dynamic heterogeneous panel data analysis. Renew. Sustain. Energy Rev. 2016, 65, 489-506. [CrossRef]

55. Chang, S.C. Effects of financial developments and income on energy consumption. Int. Rev. Econ. Financ. 2015, 35, 28-44. [CrossRef]

56. Zhang, Y.J. The impact of financial development on carbon emissions: An empirical analysis in China. Energy Policy 2011, 39, 2197-2203. [CrossRef]

57. Komal, R.; Abbas, F. Linking financial development, economic growth and energy consumption in Pakistan. Renew. Sustain. Energy Rev. 2015, 44, 211-220. [CrossRef]

58. Ang, J.B. What are the mechanisms linking financial development and economic growth in Malaysia? Econ. Model. 2008, 25, 38-53. [CrossRef]

59. Sadorsky, P. The impact of financial development on energy consumption in emerging economies. Energy Policy 2010, 38, 38-53. [CrossRef]

60. Shahhaz, M.; Lean, H.H. Does financial development increase energy consumption? The role of industrialization and urbanization in Tunisia. Energy Policy 2012, 40, 437-439.

61. Coban, S.; Topcu, M. The nexus between financial development and energy consumption in the EU: A dynamic panel data analysis. Energy Econ. 2013, 39, 81-88. [CrossRef]

62. Sadorsky, P. Financial development and energy consumption in central and eastern European frontier economies. Energy Policy 2011, 39, 999-1006. [CrossRef]

63. Christopoulos, D.K.; Tsionas, E.G. Financial development and economic growth: Evidence from panel unit root and cointegration tests. J. Dev. Econ. 2004, 73, 55-74. [CrossRef]

64. Shahbaz, M.; Hoang, T.H.V.; Mahalik, M.K.; Roubaud, D. Energy consumption, financial development and economic growth in India: New evidence from a nonlinear and asymmetric analysis. Energy Policy 2017, 63, 199-212. [CrossRef]

65. IEA (International Energy Agency). World Energy Investment Outlook: Special Report; IEA: Paris, France, 2014.

66. Best, R. Switching towards coal or renewable energy? The effects of financial capital on energy transitions. Energy Econ. 2017, 63, 75-83. [CrossRef]

67. Sbia, R.; Shahbaz, M.; Hamdi, H. A contribution of foreign direct investment, clean energy, trade openness, carbon emissions and economic growth to energy demand in UAE. Econ. Model. 2014, 36, 191-197. [CrossRef]

68. Zheng, D.; Shi, M.J. Multiple environmental policies and pollution haven hypothesis: Evidence from China's polluting industries. J. Clean. Prod. 2017, 141, 295-304. [CrossRef]

69. Shahbaz, M.; Solarin, S.A.; Mahmood, H.; Arouri, M. Does financial development reduce $\mathrm{CO}_{2}$ emissions in Malaysian economy? A time series analysis. Econ. Model. 2013, 35, 145-152. [CrossRef]

70. Jalil, A.; Feridun, M. The impact of growth, energy and financial development on the environment in China: A cointegration analysis. Energy Econ. 2011, 33, 284-291. [CrossRef]

71. Salahuddin, M.; Gow, J.; Ozturk, I. Is the long-run relationship between economic growth, electricity consumption, carbon dioxide emissions and financial development in Gulf Cooperation Council Countries robust? Renew. Sustain. Energy Rev. 2015, 51, 317-326. [CrossRef]

72. Mulali, U.A.; Sab, C.N. The impact of energy consumption and $\mathrm{CO}_{2}$ emission on the economic and financial development in 19 selected countries. Renew. Sustain. Energy Rev. 2012, 16, 4365-4369. [CrossRef]

73. Mulali, U.A.; Sab, C.N. The impact of energy consumption and $\mathrm{CO}_{2}$ emission on the economic growth and financial development in the Sub Saharan African countries. Energy 2012, 39, 180-186. [CrossRef]

74. Dogan, E.; Seker, F. The influence of real output, renewable and non-renewable energy, trade and financial development on carbon emissions in the top renewable energy countries. Renew. Sustain. Energy Rev. 2016, 60, 1074-1085. [CrossRef]

75. Ozturk, I.; Acaravci, A. The long-run and causal analysis of energy, growth, openness and financial development on carbon emissions in Turkey. Energy Econ. 2013, 36, 262-267. [CrossRef] 
76. Abbasi, F.; Riaz, K. CO $\mathrm{CO}_{2}$ emissions and financial development in an emerging economy: An augmented VAR approach. Energy Policy 2016, 90, 102-114. [CrossRef]

77. Gokmenoglu, K.; Ozatac, N.; Eren, B.M. Relationship between industrial production, financial development and carbon emissions: The case of Turkey. Procedia Econ. Financ. 2015, 25, 463-470. [CrossRef]

78. Boutabba, M.A. The impact of financial development, income, energy and trade on carbon emissions: Evidence from the Indian economy. Econ. Model. 2014, 40, 33-41. [CrossRef]

79. You, W.H.; Zhu, H.M.; Yu, K.M.; Peng, C. Democracy, financial openness, and global carbon dioxide emissions: Heterogeneity across existing emission levels. World Dev. 2015, 66, 189-207. [CrossRef]

80. Tang, C.F.; Tan, B.W. The impact of energy consumption, income and foreign direct investment on carbon dioxide emissions in Vietnam. Energy 2015, 79, 447-454. [CrossRef]

81. Wang, S.J.; Li, Q.Y.; Fang, C.L.; Zhou, C.S. The relationship between economic growth, energy consumption, and $\mathrm{CO}_{2}$ emissions: Empirical evidence from China. Sci. Total Environ. 2016, 542, 360-371. [CrossRef] [PubMed]

82. Wang, Y.F.; Ma, X.D.; Joyce, M.J. Reducing sensor complexity for monitoring wind turbine performance using principal component analysis. Renew. Energy 2016, 97, 444-456. [CrossRef]

83. Zhang, M.; Su, B. Assessing China's rural household energy sustainable development using improved grouped principal component method. Energy 2016, 113, 509-514. [CrossRef]

84. Faed, A.; Chang, E.; Saberi, M.; Hussain, O.; Azadeh, A. Intelligent customer complaint handling utilising principal component and data envelopment analysis (PDA). Appl. Soft Comput. 2016, 47, 614-630. [CrossRef]

85. Shannon, C.E. A mathematical theory of communication. Bell Syst. Tech. J. 1948, 27, 279-423. [CrossRef]

86. Delgado, A.; Romero, I. Environment conflict analysis using an integrated grey clustering and entropy-weight method: A case study of a mining project in Peru. Environ. Model. Softw. 2016, 77, 108-121. [CrossRef]

87. Wang, Q.; Wu, C.; Sun, Y. Evaluating corporate social responsibility of airlines using entropy weight and grey relation analysis. J Air Transp. Manag. 2015, 42, 55-62. [CrossRef]

88. Zou, Z.H.; Yun, Y.; Sun, J.N. Entropy method for determination of weight of evaluating in fuzzy synthetic evaluation for water quality assessment indicators. J. Environ. Sci. 2006, 18, 1020-1023. [CrossRef]

89. Chen, S.; Leng, Y.; Mao, B.; Liu, S. Integrated weight-based multi-criteria evaluation on transfer in large transport terminals: A case study of the Beijing south railway Station. Transp. Res. Part A Policy Pract. 2014, 66, 13-26. [CrossRef]

90. Srivastav, R.; Simonovic, S. An analytical procedure for multi-site, multi-season streamflow generation using maximum entropy bootstrapping. Environ. Model. Softw. 2014, 59, 59-75. [CrossRef]

91. Neill, O.; Liddle, B.; Jiang, L.; Smith, K.; Pachauri, S.; Dalton, M.; Fuchs, R. Demographic change and carbon dioxide emissions. Lancet 2012, 380, 157-164. [CrossRef]

92. Binder, M.; Offermanns, C.J. International Investment Positions and Exchange Rate Dynamics: A Dynamic Panel Analysis. Discussion Paper. 2007. Available online: https://www.researchgate.net/publication/ 5002596 (accessed on 8 May 2016).

93. China Energy Statistical Yearbook (2014), Regional Energy Balanced Sheet (Quantity). Available online: http:/ / free.xiaze.com/nianjian/zgnytjnj2013/ (accessed on 5 April 2016).

94. IPCC (Intergovernmental Panel on Climate Change). IPCC Guidelines for National Greenhouse Gas Inventories. Available online: http:/ / www.ipcc-nggip.iges.or.jp/public/gl/guidelin/ch1ri.pdf (accessed on 8 May 2016).

95. Li, K.; Qi, S.Z. Trade openness, economic growth and $\mathrm{CO}_{2}$ emission of China. Econ. Res. 2011, 11, 60-72. (In Chinese)

96. Cement data, CEinet Statistics Database. Available online: http:/ / db.cei.gov.cn (accessed on 8 May 2016).

97. Sheng, P.F.; Guo, X.H. The long-run and short-run impact of urbanization on carbon dioxide emissions. Econ. Model. 2016, 53, 208-215. [CrossRef]

98. Luintel, K.B.; Khan, M.; Gonzalez, R.L.; Li, G.G. Financial development, structure and growth: New data, method and results. J. Int. Financ. Mark. Inst. Money 2016, 43, 95-112. [CrossRef]

99. Kim, S.H.; Lin, S.C.; Chen, T.C. Financial structure, firm size and industry growth. Int. Rev. Econ. Financ. 2014, 41, 23-39. [CrossRef]

100. Lim, C.C.; Mcnelis, P.D. Income growth and inequality: The threshold effects of trade and finanical openness. Econ. Model. 2016, 58, 403-412. [CrossRef] 
101. Trabelsi, M.; Cherif, M. Capital account liberalization and financial deepening: Does the private sector matter? Q. Rev. Econ. Financ. 2017, 64, 141-151. [CrossRef]

102. Luo, Y.; Tanna, S.; Vita, G.D. Financial openness, risk and bank efficiency: Cross-country evidence. J. Financ. Stab. 2016, 24, 132-148. [CrossRef]

103. Riain, S.O.; Curry, E.; Harth, A. XBRL and open data for global financial ecosystems: A linked data approach. Int. J. Account. Inf. Syst. 2012, 13, 141-162. [CrossRef]

104. Pesaran, M.H. General diagnostic tests for cross section dependence in panels. CWPE 2004, 7, 1240.

105. Kim, D.H.; Lin, S.C.; Suen, Y.B. Dynamic effects of trade openness on financial development. Econ. Model. 2010, 27, 254-261. [CrossRef]

106. Pesaran, M. A simple panel unit root test in the presence of cross-section dependence. J. Appl. Econ. 2003, 22, 265-312. [CrossRef]

107. Baek, J. A new look at the FDI-income-energy-environment nexus: Dynamic panel data analysis of ASEAN. Energy Policy 2016, 91, 22-27. [CrossRef]

108. Westerlund, J. Testing for error correction in panel data. Oxf. Bull. Econ. Stat. 2007, 69, 709-748. [CrossRef]

(C) 2017 by the authors. Licensee MDPI, Basel, Switzerland. This article is an open access article distributed under the terms and conditions of the Creative Commons Attribution (CC BY) license (http:/ / creativecommons.org/licenses/by/4.0/). 